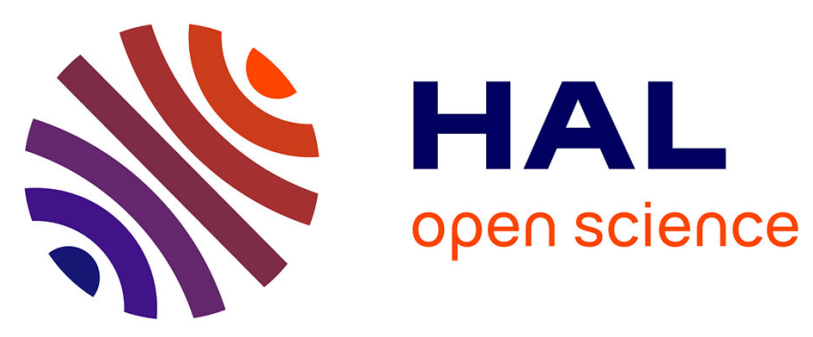

\title{
Mineralogy and Geochemistry of Laterites from the Morro dos Seis Lagos Nb (Ti, REE) Deposit (Amazonas, Brazil).
}

Arthur L. Giovannini, Artur C. Bastos, Claudio G. Porto, Vitor P. Pereira, Luc Takehara, Luc Barbanson, Pedro H.S. Bastos

\section{To cite this version:}

Arthur L. Giovannini, Artur C. Bastos, Claudio G. Porto, Vitor P. Pereira, Luc Takehara, et al.. Mineralogy and Geochemistry of Laterites from the Morro dos Seis Lagos Nb (Ti, REE) Deposit (Amazonas, Brazil).. Ore Geology Reviews, 2017, 88, pp.461-480. 10.1016/j.oregeorev.2017.05.008 . insu-01525881

\section{HAL Id: insu-01525881 \\ https://hal-insu.archives-ouvertes.fr/insu-01525881}

Submitted on 22 May 2017

HAL is a multi-disciplinary open access archive for the deposit and dissemination of scientific research documents, whether they are published or not. The documents may come from teaching and research institutions in France or abroad, or from public or private research centers.
L'archive ouverte pluridisciplinaire HAL, est destinée au dépôt et à la diffusion de documents scientifiques de niveau recherche, publiés ou non, émanant des établissements d'enseignement et de recherche français ou étrangers, des laboratoires publics ou privés.

\section{(1) (1) $\$$}

Distributed under a Creative Commons Attribution - NonCommercial - NoDerivatives 44.0 


\section{Accepted Manuscript}

Mineralogy and Geochemistry of Laterites from the Morro dos Seis Lagos $\mathrm{Nb}$

(Ti, REE) Deposit (Amazonas, Brazil).

Arthur L. Giovannini, Artur C. Bastos Neto, Claudio G. Porto, Vitor P. Pereira, Lucy Takehara, Luc Barbanson, Pedro H.S. Bastos

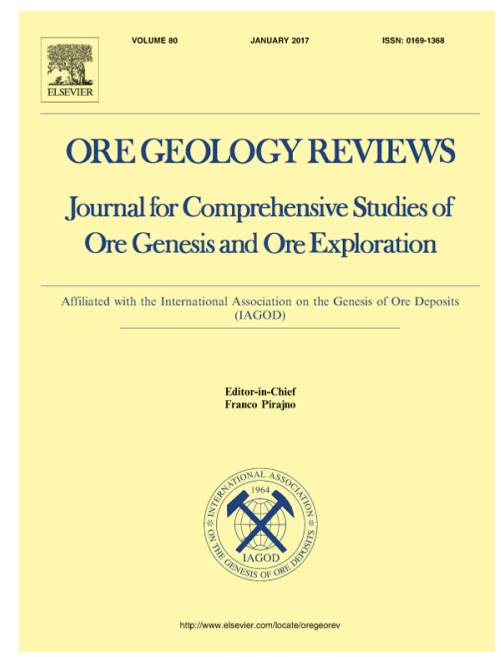

To appear in: $\quad$ Ore Geology Reviews

Received Date: $\quad 19$ July 2016

Accepted Date: $\quad 7$ May 2017

Please cite this article as: A.L. Giovannini, A.C. Bastos Neto, C.G. Porto, V.P. Pereira, L. Takehara, L. Barbanson, P.H.S. Bastos, Mineralogy and Geochemistry of Laterites from the Morro dos Seis Lagos Nb (Ti, REE) Deposit (Amazonas, Brazil)., Ore Geology Reviews (2017), doi: http://dx.doi.org/10.1016/j.oregeorev.2017.05.008

This is a PDF file of an unedited manuscript that has been accepted for publication. As a service to our customers we are providing this early version of the manuscript. The manuscript will undergo copyediting, typesetting, and review of the resulting proof before it is published in its final form. Please note that during the production process errors may be discovered which could affect the content, and all legal disclaimers that apply to the journal pertain. 
Mineralogy and Geochemistry of Laterites from the Morro dos Seis Lagos Nb (Ti, REE) Deposit (Amazonas, Brazil).

Arthur L. GIOVANNINI ${ }^{1}$, Artur C. BASTOS NETO $^{2}$, Claudio G. PORTO ${ }^{3,4}$, Vitor P. PEREIRA $^{2}$, Lucy TAKEHARA ${ }^{5}$, Luc BARBANSON ${ }^{6}$, Pedro H.S. BASTOS ${ }^{2}$

1 Programa de Pós-graduação em Geociências, Instituto de Geociências, Universidade Federal do Rio Grande do Sul. Avenida Bento Gonçalves 9500, Porto Alegre, 91501-970, RS, Brasil. arthur_giovannini@hotmail.com.

2 Instituto de Geociências, Universidade Federal do Rio Grande do Sul. Avenida Bento Gonçalves 9500, 91501-970, Porto Alegre, RS, Brasil. artur.bastos@ufrgs.br, vitor.pereira@ufrgs.br,ph_bastos@hotmail.com

3 Divisão de Geoquímica, DGM, Companhia de Pesquisa de Recursos Minerais CPRM. Avenida Pasteur 404, Urca, Rio de Janeiro, 22290-240, RJ, Brasil. claudio.porto@cprm.gov.br.

${ }^{4}$ Instituto de Geociências, Universidade Federal do Rio de Janeiro. Cidade Universitária, Ilha do Fundão, Avenida Athos da Silveira Ramos s/n, 21949-900, Rio de Janeiro, RJ, Brasil. porto@geologia.ufrj.br.

5 Companhia de Pesquisa de Recursos Minerais CPRM. SUREG/PA. Rua Banco da Província, 105, Porto Alegre, RS, Brasil. lucytakehara@gmail.com.

${ }^{6}$ ISTO, Universitéd'Orléans, Bâtiment Géosciences, rue de St. Amand, BP 6759, F-45067 Orléans, Cedex 2, France 


\section{ABSTRACT}

The Morro dos Seis Lagos niobium deposit (2897.9 $\mathrm{Mt}$ at $2.81 \mathrm{wt} \% \mathrm{Nb}_{2} \mathrm{O}_{5}$ ) is associated with laterites formed by the weathering of siderite carbonatite. This iron-rich lateritic profile ( $>100 \mathrm{~m}$ in thickness) is divided into six textural and compositional types, which from the top to the base of the sequence is: (1) pisolitic laterite, (2) fragmented laterite, (3) mottled laterite, (4) purple laterite, (5) manganiferous laterite, and (6) brown laterite. All the laterites are composed mainly of goethite (predominant in the lower and upper varieties) and hematite (predominant in the intermediate types, formed from goethite dehydroxylation). The upper laterites were reworked, resulting in goethite formation. In the manganiferous laterite (10 $\mathrm{m}$ thick), the manganese oxides (mainly hollandite, with associated cerianite) occur as veins or irregular masses, formed in a late event during the development of the lateritic profile, precipitated from a solution with higher oxidation potential than that for $\mathrm{Fe}$ oxides, closer to the water table. Siderite is the source for the $\mathrm{Mn}$. The main $\mathrm{Nb}$ ore mineral is $\mathrm{Nb}$-rich rutile (with $11.26-22.23$ wt.\% $\mathrm{Nb}_{2} \mathrm{O}_{5}$ ), which occurs in all of the laterites and formed at expense of a former secondary pyrochlore, together with Ce-pyrochlore (last pyrochore before final breakdown), Nb-rich goethite and minor cerianite. The paragenesis results of lateralization have been extremely intense. Minor $\mathrm{Nb}$-rich brookite formed from $\mathrm{Nb}$-rich rutile occurs as broken spherules with an "oolitic" (or Liesegang ring structure). Nbrich rutile and $\mathrm{Nb}$-rich brookite incorporate $\mathrm{Nb}$ following the $\left[\mathrm{Fe}^{3+}+(\mathrm{Nb}, \mathrm{Ta})\right.$ for 2Ti] substitution and both contain up to $2 \mathrm{wt} \% \mathrm{WO}_{3}$. The laterites have an average $\mathrm{Nb}_{2} \mathrm{O}_{5}$ content of 2.91 wt. $\%$ and average $\mathrm{TiO}_{2} 5.00$ wt.\% in the upper parts of the sequence. Average $\mathrm{CeO}_{2}$ concentration increases with increasing depth, from 0.12 wt.\% in the pisolitic type to 3.50 wt.\% in the brown laterite. HREE concentration is very low.

\section{INTRODUCTION}

Niobium is a lithophile transition metal that is mainly used as ferroniobium alloys in the manufacturing of high-strength low-alloy steels. The global production has quadrupled since 2000, and the demand is projected to rise. The average $\mathrm{Nb}$ abundance in the Earth's laterite is $8 \mathrm{ppm}$ (Rudnick and Gao, 2003). $\mathrm{Nb}$ is concentrated to potentially economic levels in carbonatite and alkali-silicate igneous rocks and their weathering products. The bulk of 
global $\mathrm{Nb}$ production originates from pyrochlore mineralization associated with carbonatites or their weathering products. Consequently, the majority of currently active $\mathrm{Nb}$ exploration projects around the world are focusing on fresh or weathered carbonatites as their primary target (Mitchell, 2015; Chakhmouradian, 2006; Chakhmouradian et al., 2015; Mariano and Mariano, 2012).

The Brazilian reserve of $\mathrm{Nb}$ is $10,693,520 \mathrm{t} \mathrm{Nb}_{2} \mathrm{O}_{5}$ (Pereira 2014). This country supplies approximately $92 \%$ of the world market, and the production essentially comes from the Araxá and Catalão mining districts, whose production capacities are, respectively, 6 $\mathrm{Mt} /$ year and 1.3 Mt/year of pyrochlore ore (ROM), with grades between $0.51 \mathrm{wt}$ \% and 2.71 wt.\%. In 2013, these districts produced 73,668 t of niobium contained in $\mathrm{Nb}_{2} \mathrm{O}_{5}$ concentrate, $46,555 \mathrm{t}$ of $\mathrm{Fe}-\mathrm{Nb}$ alloy and 6,200 $\mathrm{t}$ of niobium oxide and derivatives. In addition, Brazil has the Morro dos Seis Lagos deposit, whose reserves (2897.9 Mt at 2.81\% $\mathrm{Nb}_{2} \mathrm{O}_{5}$, Justo and Souza 1984, 1986) are still untouched.

The Morro dos Seis Lagos deposit, associated with the Seis Lagos Carbonatite Complex (Issler and Silva, 1980), is located in the Amazon rainforest, in the northwestern part of Amazon State (Brazil). This deposit stands out among the nineteen key examples of $\mathrm{Nb}$ deposits associated with carbonatites selected by Chakhmouradian et al. (2015) as being the world's largest $\mathrm{Nb}$ deposit and for being the only one associated with siderite carbonatite. To our knowledge, the Morro dos Seis Lagos deposit is the only case of a world-class deposit, no matter the type of metal, associated with siderite carbonatite. Regardless its economic importance and geological uniqueness, few studies have been conducted on the occurrence.

In 2011, this research team began to investigate the carbonatite and associate $\mathrm{Nb}$ deposit, followed by a study by Giovannini (2013). The primary objective of the present work is to characterize the texture, mineralogy and geochemistry of the laterites that correspond to the ore of the Morro dos Seis Lagos deposit. The Seis Lagos carbonatite will be the subject to a separate article (Giovannini et al., in prep.). However, to provide a broader vision of the mineralization, some of our data on the geological setting and the carbonatite are presented here. 


\section{BACKGROUND INFORMATION}

The Seis Lagos Carbonatite Complex consists of three circular bodies discovered in the 1970's by the RADAM Project (Pinheiro et al., 1976). Some months after the discovery, the Companhia de Pesquisa de Recursos Minerais (CPRM), still the holder of the mineral rights, conducted an exploration program (Viegas Filho and Bonow, 1976) in the major body, the Morro dos Seis Lagos (Six Lakes Hill) (Fig. 1), that evidenced this hill is capped by an iron-rich laterite that corresponds to the Morro dos Seis Lagos Nb deposit. The Morro dos Seis Lagos deposit is located within the Balaio Indigenous Territory, within the Pico da Neblina National Park, and within the Morro dos Seis Lagos Biological Reserve of the Amazonas State. The national park and the biological reserve were created after the discovery of the deposit.

Fig. 1

\subsection{Geological setting}

The Seis Lagos Carbonatite Complex is located in Guyana Shield, in the Amazonas Craton, in the southeastern part of the Rio Negro Province (Santos et al. 2000). The basement is represented by the Cauaburi Complex (Fig. 1), which groups together porphyritic metagranitoids, tonalites, monzonitic orthogneisses, augen gneisses, amphibolites, and migmatites, which are foliated in a NE-SW direction (Almeida et al., 2002, 2007), with an age of approximately $1.8 \mathrm{Ga}$ (Santos et al 2000, 2003; CPRM 2006). The wall rock of the carbonatite body is a monzogranitic augen gneiss. The $\mathrm{U}-\mathrm{Pb}$ age of zircons from the carbonatite provided two populations of ages: $\sim 1.8 \mathrm{Ga}$ and $\sim 1.3 \mathrm{Ga}$ (Rossoni et al. submitted). The age of $1.3 \mathrm{Ga}$ is interpreted as the maximum age for the Seis Lagos Carbonatite Complex.

The emplacement of the carbonatite complex was controlled by an E-W lineament that can be followed in an aeromagnetic maps for more than $400 \mathrm{~km}$. Near the complex, the most prominent structures have an E-W direction, although NE-SW and WNW-ESE structures are also found (Rossoni et al., 2016). 
The Morro dos Seis Lagos (elevation approximately $400 \mathrm{~m}$ ) stands out from a fairly flat terrain with an average elevation of approximately $90 \mathrm{~m}$ (Fig. 2). The six lakes occur on laterites (Fig. 1 and 3A) or at intermediate altitudes, in talus zones (Fig. 1 and 3B). The circular shape of the Morro dos Seis Lagos body is outlined by the base of the talus deposit (Fig. 1 and 2). However, the shape at a higher elevation (yellow and red) resembles a polygon (Fig. 2). The hill has linear edges on all sides of the polygon, except the NW edge, which presumably had a NE-SW direction but was interrupted by valleys controlled by NNW-SSE structures (Fig. 2). The remarkably rectilinear boundaries suggest that the intrusion was controlled by brittle structures. The relief on the hill is controlled by NNE-SSW structures in the NE part, by a NNE-SSW structure in the central part and by an E-W structure in the southern part (Fig. 2). All the lakes and a number of depressions filled by clays (assigned as sediments in Fig. 1) are associated with these structures (Rossoni et al., 2016).

The top of the lateritic profiles in many places in Amazonia are formed by hardened ferruginous horizons frequently called iron crust or ferricrete, which gives rise to landforms called "iron-hat" (Angélica and Costa, 1993). In this work we use the term laterite, which was originally applied by Buchanan (1807) to a Fe-rich material in Kerala (India). The Morro dos Seis Lagos laterite corresponds to iron crust (Walter, 1915), which, according to Anand and Pain (2002), encompasses the lateritic gravel together and the lateritic duricrust (Anand and Butt, 1988), as well as the ferricrete (Ollier and Galloway, 1990).

Fig. 2.

Fig. 3

The Amazon region has been subjected to deep weathering under tropical conditions since at least the Eocene (Vasconcellos et al., 1994). The resulting regolith profile may be more than $100 \mathrm{~m}$ thick showing features that reflect successive weathering episodes such as in the Carajás region where the upper zones of iron crusts are overprinted by a late bauxitization event (Porto, 2016). The iron crusts may occur forming an approximately continuous layer following ancient planation surfaces or, more locally, reflecting bedrock 
types as in the case of the Seis Lagos Carbonatite Complex and other carbonatite complexes in the Amazon region (Angélica et al, 1993). Deep weathering under these conditions may result in the formation of numerous types of ore deposits as in the Carajás region (Porto, 2010; Costa, 1997) and elsewhere in the Amazon (Costa et al, 1993).

\subsection{Previous investigations of the Morro dos Seis Lagos Deposit}

The first exploration program (Viegas and Bonow, 1976) consisted of the geological mapping and the drilling of four boreholes (Fig. 1). Borehole SG-01-AM was located over the $\mathrm{Nb}$-mineralized laterite and will be described in detail below. Borehole SG-02-AM intersected non-mineralized laterite (formed from the gneiss) $(0-34.00 \mathrm{~m})$, fenitized gneiss $(34.00$ - $222.60 \mathrm{~m})$, and carbonatite $(221.60$ - $227.70 \mathrm{~m})$; the $227.70-230.85 \mathrm{~m}$ interval was not recovered. Borehole SG-03-AM intersected non-mineralized laterite $(0-9.00 \mathrm{~m})$, saprolitized gneiss $(9.00-50.00 \mathrm{~m})$, and fresh gneiss $(50.00-110.00 \mathrm{~m})$.

Borehole SG-04-AM (Fig. 1), located in a depression named the Esperança basin, intersected from the surface to $233.65 \mathrm{~m}$ a sedimentary package composed of carbonaceous clays (lake sediments) and from 233.65 to $493.00 \mathrm{~m}$ "carbonatic" breccias. These breccias were recognized as carbonatite by Issler and Silva (1980). The palynological analysis of the lake sediments indicates a Neogene age (2.58 Ma to 23.03 Ma) (Viegas and Bonow, 1976). Bonow and Issler (1980) highlighted the anomalous concentrations of rare earth elements (REE) in the carbonaceous clays from 14.65 to $73 \mathrm{~m}$ and estimated for this section a reserve of $7.8 \mathrm{Mt}$ at 1.5 wt. $\% \mathrm{REE}_{2} \mathrm{O}_{3}$; the mineralogical characteristics of this REE mineralization are not mentioned.

In 1982, CPRM drilled an additional four boreholes in order to calculate the $\mathrm{Nb}$ ore reserve (Justo and Souza, 1984, 1986). These boreholes were stopped at depths of approximately $90 \mathrm{~m}$ and still within the mineralized laterite. Corrêa (1996) and Corrêa and Costa (1997) conducted studies using surface samples and core pulps from drill cores collected during the first CPRM campaign. They identified mostly the same minerals described in the laterite recognized in this paper. Subsequently, the only investigations of the area have been by Giovannini (2013), which are integrated into this work. 


\section{RESEARCH MATERIAL AND METHODS}

This work is based mainly on drill cores of boreholes SG-01-AM, SG-02-AM, SG-03AM, and SG-04-AM, which were completely re-logged and sampled in May 2011 at the Departamento Nacional da Produção Mineral office in the city of Manaus, Amazonas State. The cores of the additional four boreholes drilled by CPRM in 1982 were also inspected, but the types of laterite present were found to be similar to those described in borehole SG-01$\mathrm{AM}$, upon which our analytical work is concentrated, and were thus not further investigated.

The samples were examined using optical microscopy in transmitted polarized and reflected light. X-ray diffraction (XRD) work was performed at the Instituto de Geociências of the Universidade Federal do Rio Grande do Sul (UFRGS) using a Siemens D-5000 diffractometer, equipped with $\mathrm{Cu}-\mathrm{K} \alpha$ radiation and a $\mathrm{Ni}$ filter in the range from $2^{\circ}$ to $70^{\circ} 2 \theta$ with a velocity of $0.02^{\circ} 2 \theta$ per second. X-ray data were processed with "MATCH! Phase identification from powder diffraction" developed by Cristal Impact, and compared to the Crystallography Open Database (COD) database. Semiquantitative analysis from XRD data was also performed by MATCH! based on peak height, and the results are considered relative amounts. The unit cell parameters were calculated through the UnitCellWin program using the Holland and Redfern method, 1995, goethite was refined in the orthorhombic system using the wavelength $1.540593 \AA$. In the $95 \%$ confidence interval the sigma parameters are as follows: $a=0.00126, b=0.00033, c=0.00089$. Energy-dispersive X-ray spectroscopy (EDS) analyses were performed at the Centro de Microscopia Eletrônica (CME-UFRGS) using a JEOL-JSM5800 scanning electron microscope (SEM) with a voltage of $20 \mathrm{kV}$ and a spot size of $5 \mu \mathrm{m}$.

Electron microprobe wavelength dispersive analyses were first performed at the CNRS/Université d'Orléans ISTO Laboratory (Orléans, France) using a Cameca SX50 instrument. The majority of the study was performed at the Instituto de Geociências of the Universidade de Brasília using a GEOL JXA-8230 instrument. The concentrations of P, Si, $\mathrm{Ca}, \mathrm{Na}, \mathrm{K}, \mathrm{Ba}, \mathrm{Sr}, \mathrm{Al}, \mathrm{Fe}, \mathrm{Mn}, \mathrm{Ti}$, and $\mathrm{F}$ were determined with an accelerating voltage of 15 $\mathrm{kV}$ and a beam current of $10 \mathrm{nA}$. The concentrations of Nb, Ta, W, REE, Y, U, Th, and Pb were determined with an accelerating voltage of $20 \mathrm{kV}$ and a beam current of $20 \mathrm{nA}$ and a spot size of $1 \mu \mathrm{m}$. 
Whole rock geochemical analyses were provided by ACME Analytical Laboratories Ltd (Canada). Major oxides $\left(\mathrm{SiO}_{2}, \mathrm{Al}_{2} \mathrm{O}_{3}, \mathrm{Fe}_{2} \mathrm{O}_{3}, \mathrm{MgO}, \mathrm{CaO}, \mathrm{Na}_{2} \mathrm{O}, \mathrm{K}_{2} \mathrm{O}, \mathrm{TiO}_{2}, \mathrm{P}_{2} \mathrm{O}_{5}, \mathrm{MnO}\right.$, $\mathrm{Cr}_{2} \mathrm{O}_{3}$ ) and trace elements (Ba, Be, Co, Cs, Ga, Hf, Nb, Ni, Rb, Sc, Sn, Sr, Ta, Th, U, V, W, $\mathrm{Zr}$, plus 14 REE and Y) were analyzed by ICP-MS after fusion and nitric acid digestion of $0.2 \mathrm{~g}$ aliquots. Another set of trace elements (Ag, As, $\mathrm{Au}, \mathrm{Bi}, \mathrm{Cd}, \mathrm{Cu}, \mathrm{Hg}, \mathrm{Mo}, \mathrm{Ni}, \mathrm{Pb}, \mathrm{Sb}, \mathrm{Se}$, $\mathrm{Tl}, \mathrm{Zn}$ ) was analyzed by ICP-MS after aqua regia digestion of $0.5 \mathrm{~g}$ aliquots. Loss on ignition was obtained by weight difference after ignition at $1000^{\circ} \mathrm{C}$. A Leco furnace was used to measure total $\mathrm{C}$ and $\mathrm{S}$.

\section{RESULTS}

\subsection{Siderite carbonatite}

The carbonatite in drill cores of the borehole SG-02-AM (border of the Morro dos Seis Lagos carbonatite body) is a siderite carbonatite, light grey and highly friable. It is composed by siderite, barite and gorceixite, and minor monazite and pyrochlore. Siderite $(\sim 70$ vol.\%) crystals are euhedral, brownish, with average size of $700 \mu \mathrm{m}$. Some crystals are broken and present hematite at the edges and in fractures (Fig. 4A). Barite ( 15 vol.\%) occurs as aggregates of fine crystals (up to $150 \mu \mathrm{m}$ ) that fill the interstices of siderite crystals (Fig. 4A) or in veins in siderite crystals. Gorceixite (up to $7.5 \mathrm{vol} . \%$ ) occurs as the predominant mineral in aggregates (Fig. 4A, B) with monazite and pyrochlore; the crystals are euhedral, with size up to $5 \mu \mathrm{m}$. Monazite (up to 1 vol.\%) occurs mainly as small crystals fibrorradiated with up to $5 \mu \mathrm{m}$. More rarely monazite occurs filling gaps between siderite crystals (Fig. 4B). BSE images reveal that this monazite is actually aggregates of very small crystals. Pyrochlore ( $<1$ vol.\%) occurs as euhedral crystal, with $\sim 3 \mu \mathrm{m}$ in the aggregates with monazite and gorceixite.

Fig. 4

The carbonatite in the borehole SG-04-AM (central part of the Morro dos Seis Lagos carbonatite body) occurs below the sedimentary package $(0-233 \mathrm{~m})$. There is a "transitional zone" between the sedimentary package and the carbonatite. In this zone occur intercalations of: sediments with carbonatite fragments; carbonatite; and sediment and carbonatite 
fragments deposited in karstic pockets or fractures opened by dissolution of the carbonatite. Below $290 \mathrm{~m}$, the carbonatite intercalations become more abundant, thick and less weathered. Below $400 \mathrm{~m}$, the carbonatite is almost continuous and seems to be unaltered, but evidences of weathering are clear under optical microscope. All carbonatite samples are siderite carbonatite. In less altered zones, the texture is that in the Figure 4C. In most altered zones, the siderite crystals are partially dissolved, the hematite is much more abundant (Fig. 4D) and the texture both macroscopic and microscopic (optical) resembles that of a breccia.

Siderite grains (weather not partially dissolved) are euhedral, brownish, with sizes up to $500 \mu \mathrm{m}$, and frequently present trails of fluid inclusions that can be very abundant. The crystals present hematite at the edges or along fractures. The hematite zone at the edge of siderite crystals has the same texture as the small hematite crystals in the rock matrix; these hematite crystals may contain relicts of siderite (Fig. 4D), indicating that the growth of the matrix hematite occurred simultaneously with alteration on the edge of the large siderite crystals. Pyrochlore, monazite, bastnäsite, and thorbastnäsite were observed only in BSE images. Pyrochlore occurs as euhedral crystals of $\sim 5 \mu \mathrm{m}$ (Fig. 4C). Monazite occurs as agglomerate with $100 \mu \mathrm{m}$ made by crystals with $5 \mu \mathrm{m}$. Bastnäsite occurs as rare single small $(<5 \mu \mathrm{m})$ in the matrix. Thorbastnäsite occurs as acicular crystals fulfilling spaces between hematite crystals of the matrix (Fig. 4D). Gibbsite occurs as veinlets that cut siderite and hematite crystals (Fig. 4C). Quartz and gypsum were detected only by DRX in few samples.

All siderite is formed essentially by $\mathrm{Fe}^{2+}(55.26-66.25$ wt.\% $\mathrm{FeO})$, with minor amounts of $\mathrm{Mg}^{2+}$ and $\mathrm{Mn}^{2+}$; $\mathrm{Ca}^{2+}$ contents are almost negligible. Siderite from the border carbonatite is richer in $\mathrm{Mg}(\sim 4.00$ wt.\% $\mathrm{MgO})$ and $\mathrm{Mn}(5.53-11.82 \mathrm{wt} . \% \mathrm{MnO})$ than siderite from the core carbonatite $(0.19-3.12$ wt. $\% \mathrm{MgO} ; 0.82-2.16$ wt.\% MnO). Pyrochlore from border siderite carbonatite is a $\mathrm{Pb}$-Ba-pyrochlore and from the core siderite carbonatite is a $\mathrm{Ce}-\mathrm{Ba}-$-pyrochlore with up to $6.0 \mathrm{wt} . \% \mathrm{TiO}_{2}$.

Representative compositions of the siderite carbonatite are provided in Table 1. Samples from the core siderite carbonatite are the most affected by weathering because of the carstic processes that formed the Esperança basin. Low total values in samples from the border siderite carbonatite are due to the high values of $\mathrm{Ba}$, above the upper limit of detection $(50,000 \mathrm{ppm} \mathrm{Ba})$ in 2 cases. Even so, these results evidence the Seis Lagos siderite carbonatite as an extremely Fe-rich ferrocarbonatite (Fig. 5). Regarding some immobile elements important to this work, it can be noted that core siderite carbonatite has: $0.1-5.28$ wt.\% $\mathrm{TiO}_{2}$; 636.3 - 7667.4 ppm Nb; 3455.46 - 16490.96 ppm REE. The border siderite 
carbonatite is poorer in all these elements: $\sim 0.16$ wt.\% $\mathrm{TiO}_{2} ; \sim 1500$ ppm Nb; 4364.62 13312.62 ppm REE.

Fig. 5.

Table 1.

4.2. Petrography of the laterites

The laterites considered in this work were identified in drill hole SG-01-AM by relogging of the cores. Six types were defined by descriptions of macroscopic structure, texture, color and mineralogy. They are described sequentially from top to the bottom of the core as follows (Fig. 6): (1) pisolitic laterite; (2) fragmented laterite; (3) mottled laterite; (4) purple laterite; (5) manganiferous laterite; and (6) brown laterite. This drill core had a good recovery until $97.50 \mathrm{~m}$. From there to $255.25 \mathrm{~m}$, the recovery was extremely low. The material was described by Viegas and Bonow (1976) as lateritic crust, but it was not retained in the drill core boxes.

Semi-quantitative analysis of the X-ray diffraction results shows that goethite and hematite are the dominant minerals in the laterites. In the brown laterite, goethite is overwhelmingly dominant over hematite. Hematite becomes relatively more important in the lower purple laterite, manganiferous laterite, and upper purple laterite. From the fragmented laterite upwards, goethite is again enriched in relation to hematite, suggesting that these units were hydrated closer to the surface (Nahon and Tardy, 1992; Nahon, 1986). In the manganiferous laterite, the main Mn-oxide mineral is hollandite, with pyrolusite occurring only in the lowermost sample. Other important minerals detected by XRD in the fragmented laterite are $\mathrm{Nb}$-rich rutile, $\mathrm{Nb}$-rich brookite, florencite-(Ce), and rare ankerite. $\mathrm{Nb}$-rich brookite is also detected in the lower and upper purple laterite. Pyrochlore peaks were detected in the manganiferous laterite, but petrographically this mineral was only observed in the brown laterite. Detailed petrographic analysis was conducted on 35 samples selected along the drill hole length covering the 6 types of laterites (Fig. 6). These data were supported by microprobe/EDS microanalysis as given below. 
Fig. 6.

Pisolitic laterite

The pisolitic laterite occurs from the surface down to a depth of $2.2 \mathrm{~m}$ and is characterized by the predominance of a pisolitic structure alternating with more-massive ferruginous bands of different generations ranging in color from dark brown to light red and orange. Its composition is mostly goethitic $(\sim 80$ vol. $\%)$ and hematitic ( 20 vol.\%). The pisolites have an average size of $500 \mu \mathrm{m}$, and are composed of fibrous radiating goethite, which also occurs as a filling of tubular cavities (Fig. 4E). Hematite is interpreted to constitute the darker red domain which occurs lining the walls of the cavities forming a substrate onto which more-abundant goethite has precipitated (Fig. 4E). Nb-rich rutile, occurring as broken spherules, is an important accessory. These features suggest that several episodes of iron precipitation in cavities occurred, as these laterites are created closer to the surface (Nahon and Tardy, 1992; Nahon, 1986). As the precipitated Fe phases, mostly as fibrous goethite, became better crystallized, new tubular cavities developed allowing further Fe precipitation. The continuation of this process led to a reworked laterite with an intricate pattern of Fe phases precipitated in micro channels with different degrees of recrystallization, and eventually leading to a pisolitic structure.

\section{Fragmented laterite}

The fragmented material occurs in two intervals to a depth of $19.75 \mathrm{~m}$ separated by the mottled laterite (Fig. 6). It is characteristically composed of sub-rounded ferruginous fragments in different orientations. These fragments are surrounded by more-porous domains, where Fe phases were precipitated in masses or bands of different compositions (Fig. 4F). The typical fragmented texture may be due to internal collapse close to the surface, where dissolution and pedoturbation have been stronger (Anand and Paine, 2002). Goethite is the dominant mineral, but the relative importance of hematite increases compared to the overlying pisolitic laterite. Goethite occurs around nodules and fragments in a fibroousradiating pattern or filling cavities over darker red hematitic bands (Fig. 4G). Nb-rich rutile occurs as zoned and fractured greenish grains up to $125 \mu \mathrm{m}$ in size (Fig. $4 \mathrm{H})$. Also found are small $\mathrm{Nb}$-rich rutile crystals enclosed in a banded ferruginous clast representing reworked 
tubular cavities where these grains are concentrated (Fig. 4I). Minor Nb-rich brookite occurs as broken spherules. In some $\mathrm{Nb}$-rich rutile, there is a breakdown of the structure in parts of the crystal, with the formation of a gel in which the early formation of spheroidal structures can be seen. Florencite-(Ce) is a minor component; it occurs as veinlets and fills residual spaces in the laterite.

\section{Mottled laterite}

The mottled laterite occurs between $9.00 \mathrm{~m}$ and $17.00 \mathrm{~m}$. It shows vertical bands alternating between highly ferruginous hematitic dark bands and light red to orange bands of a more goethitic composition. Goethite occurs in botryoidal aggregates sometimes forming a fibro-radiating pattern. Florencite-(Ce) veinlets was identified by SEM images and EDS analysis. Nb-rich rutile (Fig. 4J) occurs as fine-zoned greenish, commonly fractured grains 75 $\mu \mathrm{m}$ in size, preferentially along more-porous tubular cavities filled by iron oxide-hydroxides. In some crystals, two types of malformed spherules occur, both apparently originating from the alteration of $\mathrm{Nb}$-rich rutile. In the first case, it seems that part of the $\mathrm{Nb}$-rich rutile turned into gel in which there is the incipient formation of spherules (Min 1 in Fig. 7A). In the second case, malformed spherules can already be individualized (Min 2 in Fig. 7B and 8A). Columbite is very rare and occurs as a relictal mineral in goethite (Fig. 8B). Veinlets of unidentified mineral rich in $\mathrm{Fe}$ and $\mathrm{Nb}$, observed only in SEM images (Fig. 8C), cut the goethite. From this depth downwards, the $\mathrm{Al}$ content of goethite, as determined by the electron microprobe, diminishes drastically. This probably reflects the hydrodynamics of the environment under to which these laterites have been subjected to closer to the surface, where Fe is frequently remobilized and reprecipitated as goethite, which is able to incorporate larger quantities of Al compared to hematite (Tardy and Nahon, 1985). Mottling has been interpreted in many lateritic profiles as a result of vegetation root penetration into softer lateritic material before the hardening of the laterite (Anand and Paine, 2002).

Fig. 7.

Purple laterite

The purple laterite is divided into the upper and lower portions, separated by the manganiferous laterite. The upper portion, between $19.75 \mathrm{~m}$ and $31.00 \mathrm{~m}$, is generally more 
porous, although it contains horizons that are more massive. It is typically more hematitic compared to the laterites above. Hematite occurs as nodules approximately $2 \mathrm{~cm}$ in size, while goethite occurs as botryoidal aggregates or forms two generations of fibro-radiating crystals (Fig. 4K). Nb-rich rutile is rare, and some crystals are cut by veinlets composed exclusively by cerianite. An outstanding feature is the more abundant occurrence of spherules of $\mathrm{Nb}$-rich brookite. They occur as nearly perfect rounded grains immersed in the ferruginous matrix (Fig. 4L and 8D) or as fractured spherules indicating brittle deformation after formation.

The lower purple laterite is $19 \mathrm{~m}$ thick and shows a similar texture to the upper purple laterite but is less porous. Goethite is mostly fibrous. Goethite and hematite are equally abundant. $\mathrm{Nb}$-rich rutile grains are more often fractured, and $\mathrm{Nb}$-bearing brookite spherules are more often malformed and commonly found as $100 \mu \mathrm{m}$ grains.

\section{Manganiferous laterite}

The manganiferous laterite occurs in the interval between $31 \mathrm{~m}$ and $40 \mathrm{~m}$. Manganese oxides in large quantities occur as veins or irregular masses that cut through the fabric of the iron-rich material. They are sub-millimeter to- centimeter in size and can form banded or brecciated patterns. The modal composition (vol.\%) of this laterite is hematite (20\% to 45\%), goethite (30\% to $68 \%$ ), hollandite $(\sim 12 \%)$, and cerianite $(1 \%)$. The parageneses in the wider Mn-bearing veins $(1 \mathrm{~cm})$ is hollandite, pyrolusite, goethite, and cerianite combined in different ways and proportions. In these veins, hollandite bands (Fig. 8E) are very homogeneous, without mineral inclusions (except for cerianite) and without alteration zones. The growth fronts of hollandite are fibrous (Fig. 8F). Hollandite also commonly occurs in the form of very thin veinlets with complex relationships. Cerianite occurs as thinner and more discontinuous bands in comparison with the other minerals (Fig. 8E) and as numerous small crystals within the hollandite bands, distributed along growing surfaces. By examining these crystals in more detail, an intergrowth between hollandite and cerianite is noted (Fig. 8G). Pyrolusite is the later mineral in the Mn-bearing veins, and occurs filling residual spaces or forming veinlets which crosscut all other minerals (Fig. 8E). Nb-rich rutile in the manganiferous laterite is a trace small $(<100 \mu \mathrm{m})$ mineral.

Fig. 8. 


\section{Brown laterite}

The brown laterite has a characteristically homogeneous texture. It occurs below 58 $\mathrm{m}$, although its entire thickness could not be determined due to the poor drill core recovery. Goethite is the dominant mineral, making up to 96 vol.\% of the laterite. Compared to the other laterites, this unit has fewer tubular cavities filled with iron precipitates, and the goethite is more evenly distributed (Fig. $8 \mathrm{H}$ ). This shows that Fe has been less remobilized, suggesting it has developed closer to the carbonatite protolith and therefore represents a lessdeveloped laterite. $\mathrm{Nb}$-rich rutile (fractured) and $\mathrm{Nb}$-rich brookite (malformed spherules) are commonly found as isolated grains, as in the laterites above. This Nb-rich rutile is similar to those described in the other laterites.

Additionally, the Nb-rich rutile was observed in sample SG-01-AM-27 (Fig. 6) and below this depth in two types of associations. In both cases, the Nb-rich rutile is malformed, contains abundant and very small mineral inclusions and the zoning is incipient. In the first association (Fig. 9A), the Nb-rich rutile occurs within a larger crystal of a non-identified mineral that is transformed into smaller crystals of secondary Ce-pyrochlore, Nb-bearing goethite, cerianite (observed only in SEM images), and $\mathrm{Nb}$-rich rutile. In one case, the $\mathrm{Nb}$ rich rutile in this association is euhedral (Fig. 9B). In the second association, which is very rare, malformed $\mathrm{Nb}$-rich rutile occurs together with very small columbite (?) crystals partially altered to goethite. In the goethite matrix, below sample SG-01-AM-27, small relict isolated crystals of Ce-pyrochlore partially altered to goethite commonly occur. In one case, we observed an association of Ce-pyrochlore and goethite (Fig. 8I) without any other mineral. In all cases, the Ce-pyrochlore presents evidences of weathering (Fig. 8I and 9B).

Fig. 9.

\subsection{Esperança Basin}

The Esperança Basin is the name given by CPRM to a karst depression filled with consolidated clay and carbonate breccia, which occurs in the upper portion of borehole SG- 
04-AM (Fig. 1C). CPRM subdivided these sediments into: kaolinite clay (9.00 - $14.65 \mathrm{~m}$ ), carbonaceous clay $(14.65-73.10 \mathrm{~m})$, clay sediment $(73.10-99.45 \mathrm{~m})$, very oxidized carbonaceous clay (99.45 - $123.85 \mathrm{~m}$ ) and carbonaceous clay plus calciferous clay (123.85 $166.55 \mathrm{~m})$. The consolidated clay overlies a sedimentary carbonate breccia (166.55 - 222.00 $\mathrm{m}$ ). The carbonatite occurs below $222.00 \mathrm{~m}$. By SEM and XRD, we identified kaolinite as the main constituent of all clay layers, with minor quartz, jarosite, and florencite in all layers. Gibbsite occurs to a depth of $15 \mathrm{~m}$. Hematite occurs just below $70 \mathrm{~m}$. Illite was identified only in highly oxidized carbonaceous clay. Florencite-(Ce), identified by EDS analysis, occurs as aggregates of authigenic crystals.

\subsection{Mineralogy}

\subsubsection{Fe oxides}

Fe oxide-hydroxides in the laterites are goethite and hematite, whose relative proportions in the vertical profile invert twice (Fig. 10A). Goethite is predominant in the lower laterites. Hematite becomes predominant in the upper purple laterite. Goethite becomes more abundant again in pisolitic and fragmented laterites, suggesting that these units have been reworked.

Representative compositions of goethite from fragmented, mottled, purple laterites and from Mn-rich rich veins are presented in Table 2. The $\mathrm{Al}_{2} \mathrm{O}_{3}$ concentration increases upwards up to 6 wt.\% (Fig. 11). Silica occurs in all goethite crystals, with a concentration up to 0.9 wt. $\% \mathrm{SiO}_{2}$, decreasing upward. Niobium and Ti were detected commonly in goethite crystals from the laterites, especially in the fragmented and mottled types, with concentrations up to 3.19 wt. $\% \mathrm{Nb}_{2} \mathrm{O}_{5}$ and $2.76 \mathrm{wt}$. $\% \mathrm{TiO}_{2}$. Manganese was detected in only half of the goethite crystals from laterites at low concentrations ( $\sim .15 \mathrm{wt} . \% \mathrm{MnO})$, reaching up to 1.1 wt. $\% \mathrm{MnO}$. Tungsten (up to 0.12 wt. $\% \mathrm{WO}_{3}$ ) and $\mathrm{Ce}$ (up to 0.2 wt. $\% \mathrm{Ce}_{2} \mathrm{O}_{3}$ ) were detected in most goethites. The goethite associated with Mn-rich veins has a distinctive composition: Mn was detected in all crystals with an average $2.0 \mathrm{wt} \% \mathrm{MnO}$. The Ce concentration reaches $0.60 \mathrm{wt} . \% \mathrm{Ce}_{2} \mathrm{O}_{3}$, and $\mathrm{Nb}$, Ti, and $\mathrm{W}$ were not detected. 
Fig. 10.

Table 2.

Fig. 11.

\subsubsection{Manganes oxides}

Hollandite, generally $\mathrm{A}_{0-2}\left(\mathrm{~B}^{2+}, \mathrm{B}^{3+}, \mathrm{Mn}^{4+}\right)_{8} \mathrm{O}_{16}$, has a structure consisting of double chains of $\mathrm{MnO}_{6}$ octahedra sharing vertices along the $c$-axis which form a square tunnel arrangement The tunnels are partially filled with large $A$-site cations, which may be mono- or divalent ( $\mathrm{K}, \mathrm{Ba}, \mathrm{Sr}$ etc). Charge compensation is achieved by substitution for $\mathrm{Mn}^{4+}$ at the octahedral $B$-sites by tri- and divalent cations, and some $\mathrm{OH}^{-}$may replace $\mathrm{O}^{2-}$ (Pasero 2005). Representative compositions of hollandite are provided in Table 3. The structural formula can be written as: $\left(\mathrm{Ba}_{0.78-0.95} \mathrm{~K}_{0-0.03} \mathrm{~Pb}_{0-0.01}\right)\left(\mathrm{Mn}^{4+}{ }_{6.42-7.18} \mathrm{Mn}^{2+}{ }_{0.32-0.85} \mathrm{Fe}^{3+}{ }_{0.02-0.90} \mathrm{Al}_{0.03-0.36}\right) \mathrm{O}_{16}$.

Table 3.

\subsubsection{Niobium minerals}

In the laterites, $\mathrm{Nb}$ minerals are $\mathrm{Nb}$-rich rutile (notably predominant), $\mathrm{Nb}$-rich brookite, secondary Ce-pyrochlore (below $79 \mathrm{~m} \mathrm{depth}$ ) and extremely rare columbite. $\mathrm{Nb}$ rich rutile has been known for 150 years, mainly under its currently varietal name ilmenorutile. Nb-rich rutile occurs in all laterites, with the crystals showing omnipresent oscillatory zoning with respect to the $\mathrm{Ti}, \mathrm{Nb}$, and $\mathrm{Fe}$ contents. The zoning is evident in optical or BSE images. Representative compositions and structural formulae are provided in Table 4. The main oxides have the following ranges: $\mathrm{TiO}_{2}\left(57.84-80.92\right.$ wt.\%), $\mathrm{Nb}_{2} \mathrm{O}_{5}(11.26-$ 22.23 wt.\%), $\mathrm{Fe}_{2} \mathrm{O}_{3}\left(8.96\right.$ - 14.95 wt.\%), up to 1.27 wt.\% $\mathrm{WO}_{3}$, and up to 1.09 wt. $\% \mathrm{SiO}_{2}$. 
The average structural formula is: $\left(\mathrm{Ti}_{0.75} \mathrm{Fe}_{0.13} \mathrm{Nb}_{0.11} \mathrm{Si}_{0.01} \mathrm{~W}_{0.01}\right) \mathrm{O}_{2}$. A distinctive feature of the $\mathrm{Nb}$-rich rutile is the absence of Ta corroborated by whole-rock analyses $(\mathrm{Ta}<2.3 \mathrm{ppm}$ in carbonatite and $\mathrm{Ta}<0,70 \mathrm{ppm}$ in the laterites).

Table 4.

The Nb-rich rutile of the brown laterite, which occurs in paragenesis with Cepyrochlore, $\mathrm{Nb}$-bearing goethite and cerianite, has composition (Table 4) very similar to that of the isolated crystals of $\mathrm{Nb}$-rich rutile. Figure 12A suggests that there are two compositional types with respect to the main elements ( $\mathrm{Ti}, \mathrm{Fe}$ and $\mathrm{Nb}$ ), but more analysis is needed to confirm this division.

Fig. 12.

$\mathrm{Nb}$-rich brookite occurs in all types of laterites in small amounts, except in the purple variety, in which there is a concentration of spherules, in contrast to the rarity of Nb-rich rutile in this unit. Representative compositions and structural formulae are provided in Table 5. The main oxides have the following ranges: $\mathrm{TiO}_{2}(68.23-82.99 \mathrm{wt} . \%), \mathrm{Nb}_{2} \mathrm{O}_{5}(10.43-$ 16.446 wt.\%), $\mathrm{Fe}_{2} \mathrm{O}_{3}\left(7.65\right.$ - 13.87 wt.\%), up to 1.2 wt.\% $\mathrm{WO}_{3}$, and up to 0.97 wt.\% $\mathrm{SiO}_{2}$. The average structural formula is $\left(\mathrm{Ti}_{0.79} \mathrm{Fe}_{0.11} \mathrm{Nb}_{0.08} \mathrm{Si}_{0.01} \mathrm{~W}_{0.01}\right) \mathrm{O}_{2}$. Compared with Nb-rich brookite, the Min 2 spherules are richer in $\mathrm{Nb}$ and $\mathrm{Fe}$ and poorer in Ti. This is likely a $\mathrm{Nb}-\mathrm{Fe}-$ rich brookite.

Table 5 .

These spherules exhibit structures similar to Liesegang rings. Some of these structures are perfect, apparently without any interference in growth. They also occur in pairs of rings with initial growth from two distinct nuclei that do not touch, i.e they began to grow 
simultaneously. Some fragments have overgrowth of other bands. The colors of the bands reflect compositional variations. The BSE images show that these bands are composed of other minor bands.

The best charge balance for $\mathrm{Nb}$-rich rutile and $\mathrm{Nb}$-rich brookite was achieved with all iron as $\mathrm{Fe}^{3+}$. Nb-rich rutile incorporates $\mathrm{Nb}$ following the coupled substitution $\left[\mathrm{Fe}^{3+}+(\mathrm{Nb}\right.$, Ta) for 2Ti] (Fig. 12B) with few deviations from the ideal. Nb-rich brookite presents a significant deviation, while Min 2 diverges from this substitution.

Representative compositions of the Ce-pyrochlore are given in Table 6. Many crystals present low total and are very poor in $\mathrm{Na}$ and $\mathrm{Ca}$ corroborating the petrographic evidences of weathering (Wall et al., 1996). Fluorine was not detected. $\mathrm{Ce}_{2} \mathrm{O}_{3}$ varies from 12.16 to 28.25 wt.\%. Pb concentration varies from $1.4 \%$ a 11.36 wt.\%. Ba concentration varies from 0.18 to $4.61 \mathrm{wt}$. \%. The correlation between vacancy at A-site, loss of Ce and the vertical distribution of the samples is very prominent (Fig. 13).

Fig. 13.

Table 6.

\subsubsection{Rare Earth Elements Minerals}

The Rare Earth Elements (REE) minerals in the laterites are cerianite and florencite(Ce). REE were also detected in low concentrations in several microprobe analyses performed in amorphous, poorly crystalline and crystalline Fe-oxide-hydroxides. Ce, with a concentration up to 0.2 wt. $\% \mathrm{Ce}_{2} \mathrm{O}_{3}$, is the main REE in these minerals. Microprobe analysis show that both cerianite associated with hollandite in the manganiferous laterite and cerianite in veinlets from the purple laterite are almost entirely composed of Ce with low concentrations of $\mathrm{Gd}, \mathrm{Nd}, \mathrm{Yb}$, and $\mathrm{Lu} ; \mathrm{F}$ is present in many cases. 
Florencite occurs in the upper laterites, where it was detected only by XRD, and in sediments of the Esperança basin. EDS analysis indicates that Ce is the main REE in almost all cases. Nd is always present but is the main REE only in a few cases.

\subsection{Geochemistry}

The compositions of representative samples of all types of laterites are presented in Table 7. The LOI values range from 6 to $10 \mathrm{wt} \%$ (Fig. 10B), and reflect the goethite abundance. All samples from the laterite profile have high iron content $\left(\sim 80\right.$ wt. $\left.\% \mathrm{Fe}_{2} \mathrm{O}_{3}\right)$, except the manganiferous type, which can contain up to $32 \mathrm{wt} \% \mathrm{MnO}$, diluting the iron concentration to as low as nearly $\sim 55$ wt. $\% \mathrm{Fe}_{2} \mathrm{O}_{3}$ (Fig. 10B). $\mathrm{MgO}, \mathrm{CaO}, \mathrm{Na}_{2} \mathrm{O}$ and $\mathrm{K}_{2} \mathrm{O}$ occur with very low concentrations or are not detected $(<0.01 \mathrm{wt} . \%)$.

The $\mathrm{Al}_{2} \mathrm{O}_{3}$ content of the fragmented, mottled and pisolitic laterites may reach 3.6 wt.\% (Fig. 10D). A similar enrichment trend is observed for $\mathrm{P}_{2} \mathrm{O}_{5}$ (Fig. 10D), which may reach up to $2.5 \mathrm{wt} . \%$ in the mottled variety. Below that, it is typically $<0.6 \mathrm{wt} . \%$, which is consistent with the low levels of $\mathrm{P}_{2} \mathrm{O}_{5}(<2.0 \mathrm{wt} . \%)$ in the primary carbonatite. The contents of $\mathrm{Zr}$, Hf, and U follow similar trends. The MnO content (Fig. 10B) is generally low, except for the manganiferous laterite (up to 32.6 wt.\%), with concomitant enrichment in $\mathrm{Ba}, \mathrm{Co}, \mathrm{Cd}$, and Tl. Cerium is also enriched in the manganiferous laterite, but there are also similarly rich $\mathrm{Ce}$ intervals in the lower purple and brown varieties. From the fragmented laterite upwards, $\mathrm{Ce}$ is depleted. The other LREE are generally depleted in the manganiferous laterite but enriched in the fragmented, mottled and pisolitic varieties. In the lower purple and brown laterites, the LREE show a more variable concentration. The concentrations of HREE and $\mathrm{Y}$ tend to be higher in the lower purple and upper portions of the brown type, but above it, including the manganiferous variety, they show an upward depletion trend.

\section{Table 7.}

Niobium and $\mathrm{Ti}$ are typically accompanied by W. High concentrations of these elements occur in the upper and lower purple laterites and upper portions of the brown type 
(Fig. 10C) - for instance, sample SG-01-AM-11 (Tab. 7) with 13217.10 ppm Nb, 7.23 wt.\% $\mathrm{TiO}_{2}$, and $380.20 \mathrm{ppm} \mathrm{W}$ - and may reflect the presence of concentrated Nb-Ti-W mineralization in the carbonatite. In the fragmented laterite and upwards, they are enriched, in common with $\mathrm{Al}, \mathrm{P}, \mathrm{Zr}$, Hf, and $\mathrm{U}$.

The parallelism between the $\mathrm{TiO}_{2} / \mathrm{Nb}_{2} \mathrm{O}_{5}$ ratios and the textural/mineralogical classification of the laterites is remarkable. In the reworked laterites (pisolitic, fragmented, and mottled), the $\mathrm{TiO}_{2} / \mathrm{Nb}_{2} \mathrm{O}_{5}$ ratios are approximately 1 (Fig. 10C). In the upper purple laterite, the $\mathrm{TiO}_{2} / \mathrm{Nb}_{2} \mathrm{O}_{5}$ ratios are approximately 2. In the lower purple laterite and brown laterite the $\mathrm{TiO}_{2} / \mathrm{Nb}_{2} \mathrm{O}_{5}$ ratios invert to $\sim 0.70$ and $\sim 0.35$ respectively.

The upward enrichment of Al, P, Zr, Hf, U, and LREE observed in the fragmented laterite suggests that these elements are residually enriched closer to the surface. However, the enrichment of $\mathrm{Al}$ and $\mathrm{P}$ may also be influenced by their incorporation into goethite, although P may also occur as secondary phosphate minerals.

Figure 14 compares the normalized distribution diagrams of lanthanides for all types of laterite, the siderite carbonatite and the clays from Esperança Basin. As is characteristic of carbonatites, the distribution pattern of the siderite carbonatite (Fig. 14) is strongly enriched in LREE, but with an unusual feature represented by a relative depletion of the $\mathrm{La}, \mathrm{Ce}$, and Pr. The siderite carbonatite has no Eu anomaly. The brown and the lower purple laterites (Fig. 14C, D) - the lowest laterites in the profile and, therefore, the least evolved - display similar REE distribution; they differ from this rock in being slightly poorer in REE (from $\mathrm{Pr}$ to $\mathrm{Lu}$ ) and by the presence of a positive $\mathrm{Ce}$ anomaly which is more pronounced in the brown laterite. The manganiferous and upper purple laterites (Fig. 14B) have similar REE distribution patterns; with regard to the carbonatite, these are depleted in REE (from Pr to $\mathrm{Lu}$ ), show an accentuated positive $\mathrm{Ce}$ anomaly and the presence of a positive Gd anomaly (Fig. 14B). The pisolitic and fragmented laterites have similar REE patterns (Fig. 14A); with regard to the carbonatite they are poorer in REE from Pr to Lu; they have small positive Ce and Gd anomalies. The REE patterns of mottled laterite and of clays from Esperança basin are similar; they are richer in LREE with respect to all of the laterites. In case of La and Ce, there is an enrichment compared to the primary rock and no positive $\mathrm{Ce}$ and $\mathrm{Gd}$ anomalies. The upper laterites (pisolitic, fragmented and mottled) and the clays of Esperança Basin are the poorer in HREE (Fig. 14A). 
Fig. 14.

4.6 Metals of economic interest

The ranges of variation and the average concentrations of oxides representing potential economic interest for each laterite are shown in Table 8. Although our sampling was not made specifically for economic evaluation, we draw attention to the similarity between the $\mathrm{Nb}_{2} \mathrm{O}_{5}$ concentrations we obtained and the average concentration for the Morro dos Seis Lagos deposit obtained by CPRM in the 1970s (2.81 wt.\% $\mathrm{Nb}_{2} \mathrm{O}_{5}$, Justo and Souza 1984).

The $\mathrm{TiO}_{2}$ concentrations (Tab. 8) are quite significant, especially to a depth of $30 \mathrm{~m}$ (pisolitic, fragmented, mottled and upper purple laterites), with an average of $5.00 \mathrm{wt} . \%$ in this section. From $31 \mathrm{~m}$ to $70 \mathrm{~m}$ [manganiferous, lower purple, and brown (upper portion) laterites], the $\mathrm{TiO}_{2}$ concentrations decrease.

The $\mathrm{W}$ concentrations of $250 \mathrm{ppm}$ in the upper laterites (Tab. 7) are associated with $\mathrm{Nb}$-rich rutile, which contains up to $2 \mathrm{wt} . \% \mathrm{WO}_{3}$, so the possibility of $\mathrm{W}$ extraction as byproduct may be considered. Zinc ( $\sim 1500 \mathrm{ppm}$ in the middle and lower laterites) and Th ( $2500 \mathrm{ppm}$ in all laterites) (Tab. 7) may also be of interest to exploration, but further mineralogical studies are required.

$\mathrm{Ce}$ is by far the most abundant REE in the laterites, in which the $\mathrm{CeO}_{2}$ concentrations range from 0.12 to $3.50 \mathrm{wt} . \%$. The increase in concentration with increasing depth is very clear, ranging from an average of $0.15 \mathrm{wt} . \%$ in the pisolitic laterite up to $1.07 \mathrm{wt} . \%$ in the brown laterite (Tab. 8). The sum of all other LREE ranges from an average of $0.13 \mathrm{wt} . \%$ $\mathrm{LREE}_{2} \mathrm{O}_{3}$ in the manganiferous laterite up to $0.63 \mathrm{wt} \% \mathrm{LREE}_{2} \mathrm{O}_{3}$ in the mottled laterite; La is the most abundant, whose content ranges from 0.02 to 0.90 wt. $\% \mathrm{La}_{2} \mathrm{O}_{3}$ (average all laterites: 0.20 wt. $\% \mathrm{La}_{2} \mathrm{O}_{3}$ ). Nd may also have economic interest. The HREE concentration is very low, as commonly occurs in carbonatites and associated deposits.

Table 8. 


\section{DISCUSSION}

The most abundant carbonates in carbonatites are calcite and dolomite, whereas ankerite, siderite, magnesite, and rhodochrosite are relatively rare. Other typical rock-forming constituents include apatite, magnetite, and ferromagnesian silicates (Mitchell, 2005; Woolley and Kjarsgaard, 2008; Chakhmouradian and Zaitsev, 2012). These minerals are virtually absent at the Seis Lagos Carbonatite Complex where siderite is the only rockforming mineral. The revised nomenclature for ferrocarbonatites (Gittins and Harmer, 1997) reclassified all previous ferrocarbonatites, except three African carbonatites: Buru, Chilwa and Kugwe. Subsequently, others ferrocarbonatites have been recognized: Swartbooisdrif (Thompson et al. 2002), Sallanlatvi (Zaitsev et al. 2004), and Gifford Creek (Pirajno et al., 2014). These ankerite- and siderite-carbonate rocks mainly occur as a minor component in many carbonatite complexes dominated by $\mathrm{Ca}-\mathrm{Mg}$ carbonatite. The Sallantvi Complex is the one with the largest bodies of siderite carbonatite (two main bodies with about $500 \mathrm{~m} \times 100 \mathrm{~m}$ in the central part of the complex) that are mineralized in pyrochlore, but have no associated lateritic deposit. The ferrocarbonatites are generally seen as the low-temperature product of fractional crystallization of Ca-Mg carbonate melts, nevertheless, some carbonatite specialists are sceptical as to whether Fe-rich carbonate magmas exist (Thompson et al., 2002). The siderite carbonatite of Sallantvi precipitated from carbo-hydrothermal fluid (Zaitsev et al. 2004). The origin of the Seis Lagos siderite carbonatite is uncertain at this point and will be the subject of a separate contribution.

With regard to $\mathrm{Ti}$ and $\mathrm{Nb}$ concentrations in siderite carbonatite, most samples from the central part of the carbonatite body (up to $5.28 \mathrm{wt} . \% \mathrm{TiO}_{2}$ and up to $7667 \mathrm{ppm} \mathrm{Nb}$, Tab. 1) allow consider this rock as a viable protolith to the deposit. $\mathrm{TiO}_{2} / \mathrm{Nb}_{2} \mathrm{O}_{5}$ ratio in $\mathrm{Nb}$-rich rutile and the $\mathrm{Nb}$-rich brookite ranges more frequently from $\sim 4$ to $\sim 7$. $\mathrm{The}^{\mathrm{TiO}} \mathrm{O}_{2} / \mathrm{Nb}_{2} \mathrm{O}_{5}$ ratios in the laterites are quite different. The differences can correspond to different protoliths but can also be interpreted as mainly due to the weathering process. In this sense, the low values in the brown laterite $(\sim 0.35)$ are attributable to the presence of relict pyrochlore; the increasing to $\sim 0.70$ in the lower purple laterite and to 2.0 in the upper purple laterite can reflect the remobilization of $\mathrm{Nb}$ liberated from pyrochlore decomposition that was not retained in Nb-rich rutile and in iron-oxides; the pisolitic, fragmented, and mottled laterites present values $\sim 1$ and these are the three laterites that were reworked. 
The sequence of pyrochlore transformation with progressive weathering has been investigated in several locations. Although the original composition of pyrochlore plays an important role in determining the variety of pyrochlore that formed, secondary pyrochlores formed by weathering processes follow more or less well-defined sequences at each locality. According to Entin et al. (1993) (in Wall et al., 1996), fresh predominantly Ca, Na pyrochlore weathers to give successive generations of strontio-, Sr,Ba-, $\mathrm{Ba}, \mathrm{Sr}-$ and then plumbopyrochlore. The trend at Mount Weld is one of progressive leaching of $\mathrm{Ca}$ and $\mathrm{Na}$ and partial replacement by varying proportions of $\mathrm{Sr}$ and $\mathrm{Ce}$ rather than $\mathrm{K}, \mathrm{Ba}$ and $\mathrm{Sr}$ (Lottermoser and England, 1988). At the Yenisei Ridge, bariopyrochlores are reported to occur lower in the profile than strontiopyrochlore (Lapin and Kulikova, 1989). At Lueshe (Wall et al., 1996), the most K-Nb-rich pyrochlore occurs at intermediate levels, the most Barich pyrochlore occurs in quartz- and clay-rich ores and close to the surface in some other drill holes, and the highest levels of Sr occur in the Ba-rich pyrochlore and near the base of weathering profiles throughout the deposit. In the $\mathrm{Nb}$-deposit of Catalão I, the pyrochlore is secondary and, with increasing weathering, it presents Ba enrichment and increasing in vacancy due to $\mathrm{Ca}$ and $\mathrm{Na}$ losses (Cordeiro et al. 2011). In the Catalão II Nb-deposit, the pyrochlore alteration is marked by $\mathrm{Ba}$ and REE enrichment (Rocha et al., 2001). Secondary Ba-pyrochlore is the $\mathrm{Nb}$ ore mineral exploited at Araxá (Silva, 1986). Given the data above, we are inclined to interpret the $\mathrm{Pb}-\mathrm{Ba}$-pyrochlore (border siderite carbonatite) as an early product of primary pyrochlore weathering, followed by Ce-Ba-pyrochlore (core siderite carbonatite, strongly weathered because of the karstic process that formed the Esperança Basin) and then by Ce-pyrochlore (lower part of the brown laterite) which is progressively weathered (Fig. 13) until disappearing in the upper part of the brown laterite.

The Morro dos Seis Lagos is the only example of a Nb-deposit where Nb-rich rutile is the main ore mineral. Minor Nb-rich rutile (together with minor ferrocolumbite) occurs in the Tomtor deposit (Kravchenko and Pokrovsky, 1995), where pyrochlore is the main ore mineral. Petrological studies of carbonatites have shown that each $\mathrm{Nb}$-deposit is unique with respect to the assemblage of Nb-bearing minerals present (Mitchell, 2015). Hence, the Oka (Bond Zone) calcite carbonatites (Canada) contain pyrochlore, perovskite and niocalite, whereas the St. Honoré dolomite carbonatites (Canada) lack perovskite and niobium silicates and, in addition to pyrochlore, contain abundant ferrocolumbite and magnetite together with minor niobian rutile. Another point to consider is the intensity of lateritization. According to Mitchell (2015), intense lateritization ultimately leads to complete decomposition of 
pyrochlore and the formation of $\mathrm{Nb}$-rich rutile, brookite, and anatase. Indeed, the lateritic profile we described is a case of extreme lateritization, where very small amounts of pyrochlore were preserved only in the deepest least evolved laterite.

At the Seis Lagos deposit, a non-identified mineral altered to form Nb-rich rutile together with Ce-pyrochlore and Nb-bearing goethite (Fig. 9). We think that this mineral was likely a secondary pyrochlore, possibly a Ce-Ba-pyrochlore, richer in Ti than those already found in the core siderite carbonatite (with up to $6.0 \mathrm{wt} \% \mathrm{TiO}_{2}$ ). Alternatively, it could be perovskite or loparite-(Ce). As the $\mathrm{Nb}$-rich rutile crystals from the different laterites are petrographically and chemically similar, there is no reason to suppose they formed from different minerals.

$\mathrm{Nb}$-bearing goethite formed by the weathering of carbonatites was described at Lueshe (Democratic Republic of the Congo) by Wall et al. (1996), who noted the difficulty of discriminating between $\mathrm{Nb}$ incorporated into the goethite structure and inclusions of pyrochlore or other secondary minerals. In some of their samples, the presence of $\mathrm{Nb}$ in goethite occurring as anhedral inclusions in crandallite was unambiguous. In other samples, from highly weathered ores, between 1.4 and $3.0 \mathrm{wt} . \% \mathrm{Nb}_{2} \mathrm{O}_{5}$ was found in goethite with no evidence of inclusions. In our samples, there is no evidence of inclusions and there is no evidence of replacement of $\mathrm{Nb}$-rich rutile by goethite, as described in the Longonjo carbonatite, Angola (Castellano et al. 2012). Thus, we consider that Nb-bearing goethite is a product of pyrochlore transformation with progressive weathering.

Spherules of $\mathrm{Nb}$-rich brookite occur in the rare metal mineralization at the Salpeterkop carbonatite complex, South Africa, where the mode of occurrence was considered compatible with metasomatic crystallization from permeating hydrothermal solutions, even though subsequent fragmentation is evident (Verwoerd et al. 1995). Our petrographic and analytical data suggest that the $\mathrm{Nb}$-rich brookite formed from $\mathrm{Nb}$-rich rutile. It is, however, an extremely complex issue. In Nb-Ta-bearing geochemical environments, rutile readily accepts $\mathrm{Nb}$ and $\mathrm{Ta}$ into its structure, mainly in tapiolite-like stoichiometry with $\mathrm{Fe}>\mathrm{Mn}$. The rutile incorporates the tapiolite component through the substitution of $3 \mathrm{Ti}^{4+}$ by $(\mathrm{Fe}, \mathrm{Mn})^{2+}+2(\mathrm{Nb}, \mathrm{Ta})^{5+}$ (Hirtopanu et al. 2015). Černý et al. (1999) considered 2 additional substitutions: $\left[\mathrm{Fe}^{3+}+(\mathrm{Nb}, \mathrm{Ta})\right.$ for $\left.2 \mathrm{Ti}\right]$ and $\left[\left(\mathrm{Fe}^{2+}, \mathrm{Mn}\right)+\mathrm{W}\right.$ for 2Ti]. These authors observed that $\mathrm{Nb}$-rich rutile is, in most cases, exsolved into a $(\mathrm{Fe}, \mathrm{Nb})$-depleted rutile + titanian ferrocolumbite or titanian ixiolite and that the relics of the original homogeneous phase are scarce and only microscopic in size. Oxidation of the primary niobian rutile phase and 
exsolution products is controlled by the $(\mathrm{Nb}, \mathrm{Ta}, \mathrm{W})$ vs $(\mathrm{Fe}, \mathrm{Mn})$ budget and by the $\mathrm{Fe}^{3+} / \mathrm{Fe}^{2+}$ budget in the primary phase. In cases of highly $\mathrm{Fe}^{2+}$ dominant rutile with $(\mathrm{Nb}, \mathrm{Ta})$ balanced by $(\mathrm{Fe}, \mathrm{Mn})$, titanian ferrocolumbite to manganocolumbite or ixiolite are the only exsolution products. In $\left(\mathrm{Fe}^{3+}, \mathrm{Sc}\right)$ dominant rutile with $(\mathrm{Nb}, \mathrm{Ta})$ balanced by $(\mathrm{Fe}, \mathrm{Mn})$, a titanian $\left(\mathrm{Fe}^{3+}\right.$, $\mathrm{Sc}) \mathrm{NbO}_{4}$ phase with a subordinate ferrocolumbite component is the only exsolution product (Černý et al. 1999).

At the Morro dos Seis Lagos Deposit, the Nb-rich rutile accommodates Nb following $\left[\mathrm{Fe}^{3+}+(\mathrm{Nb}, \mathrm{Ta})\right.$ for $\left.2 \mathrm{Ti}\right]$ substitution with few deviations from the ideal, whereas Nb-rich brookite presents a little more significant deviation (Fig. 11B). Furthermore, the stage preceding the formation of the Nb-rich brookite is represented by a breakdown of the structure in parts of the $\mathrm{Nb}$-rich rutile crystals, with the formation of a gel in which the incipient formation of spherules can be seen (Min 1, Fig 7A). The first formed spherules (Min 2, Fig. 7B) have a composition of $\mathrm{Nb}-\mathrm{Fe}$-rich brookite, but further studies are required to prove whether it is brookite. The oolitic texture can be attributed to the phenomena known as Liesegang rings (Liesegang, 1896). Liesegang rings are bands formed when diffusion leads to supersaturation and nucleation. Fine precipitation occurs when two components separate through chemical segregation during weathering, thus forming self-organizing periodic patterns.

According to Smith (1984), many experiments produce Liesegang rings. Common to most of these systems is the presence of gel/water and supersaturated solution and the product of reaction is stable. Hedges (1932) and Stern (1954), in Krug et al. (1996), argue that the interaction of specific chemical reactions and diffusion precipitation and the competitive growth of particles are responsible for the formation of ring pattern over time. In addition, several factors are involved in the formation of these rings, such as the concentration and temperature of chemical solutions, to promote the precipitation of colloids or the existence of nuclei that facilitate mineral growth. According to Krug et al. (1996), self-organizing patterns are very regular but may have many types of irregularities, with apparent displacement or branches, gaps in bands or transitions between bands and skeletal patterns.

Under oxidizing conditions siderite becomes unstable, the formation of iron oxides and hydroxides occurs. These are stable under oxidizing conditions at a wide $\mathrm{pH}$ range (Krauskopf, 1985). The occurrence of siderite is practically limited to neutral or basic conditions. The Eh elevation or $\mathrm{pH}$ decrease destabilizes siderite, which turns into different 
mineral phases or remains in solution. In the case of Seis Lagos, where the activity of S was low, the input of oxidizing and acid solutions easily destabilized siderite and formed Fe oxihydroxide. Goethite and hematite can be formed from weathering of Fe-bearing primary minerals in the early stages of weathering. Goethite is the dominant weathering product of most primary Fe-bearing minerals (siderite, biotite, pyrite, olivine and others). Hematite is mainly formed by oxidation of magnetite (Anand and Gilkes 1984; Anand and Payne, 2002). However, in more advanced weathering profiles, which is the case of Morro dos Seis Lagos deposit, hematite can be formed from dehydroxylation of goethite (Wells et al., 1989). The occurrence of hematite together with goethite may be a result of variations in hydrological conditions that affect the ageing product of goethite. These variations can explain the existence of successive phases of $\mathrm{Fe}$ oxi-hydroxides precipitation. Under aerobic conditions and in the $\mathrm{pH}$ range of a normal weathering environment, the $\mathrm{Fe}^{3+}$ oxides are very stable and persist for a long time (Anand and Payne, 2002). In the upper part of the lateritic profiles, hematite is commonly altered to goethite by rehydration (Tardy and Nahon, 1985). This occurred in the Morro dos Seis Lagos deposit during the reworking of the three upper laterites.

The precipitation of Mn oxide minerals within the laterite seems to be a late event since Mn oxides occur in fractures and cavities. The source of Mn is most likely the siderite. Under oxidizing conditions $\mathrm{Fe}$ and $\mathrm{Mn}$ can behave in different ways if such solutions are made basic suddenly, both metals will precipitate, resulting in the formation of Fe minerals with a small admixture of $\mathrm{Mn}$. If, on the other hand, the $\mathrm{pH}$ increases very slowly, $\mathrm{Fe}$ compounds reach the limit of solubility before Mn compounds and so can precipitate while $\mathrm{Mn}$ is left in solution. The Mn remaining in solution may be deposited as an oxide if conditions are oxidizing and the solution becomes still more alkaline. As the precipitation of Mn oxides from solutions requires a higher oxidation potential than that for Fe oxides, the Mn tends to precipitate closer to the water table (Krauskopf, 1985).

The configuration presented by the REE (Fig. 14) in the Morro dos Seis Lagos deposit indicates that the HREE were leached along the entire lateritic profile, especially in its upper part. The LREE were leached in the uppermost part of the profile, but were precipitated at the base of the reworked laterites (mottled laterite) and in the clays of the Esperança Basin. The positive anomalies of $\mathrm{Ce}$ are related to its tetravalent state that favors its fixation by the formation of cerianite in the laterites, with increasing concentrations with increasing in depth. Low REE contents at the top of the laterite are likely due to mobility and removal of REE 
after decalcification of the upper part of the profile, and thus during the acid stage of weathering. A similar REE distribution was described in Mount Weld (Lottermoser, 1990), where the REE were complexed by carbonate, fluoride or chloride anions, and transported down through the laterite profile. These complexes were subsequently destabilised when they encountered higher carbonate anion concentrations, increasingly higher groundwater $\mathrm{pH}$ and higher alkalinity conditions in deeper parts of the profile. LREE were deposited as phosphates and aluminophosphates in the middle portion of the supergene horizon. The LREE were separated from the HREE and Y because the latter remained stable in solutions characterised by elevated $\mathrm{pH}$ and alkalinity conditions. Lottermoser also indicated that LREE formed a high-concentration REE zone in the center of the profile due to variations in $\mathrm{pH}$ and Eh and groundwater lateral circulation. In the Morro dos Seis Lagos deposit, the LREE were deposited at the mottled laterite and the high-concentration central zone is exemplified by the high concentrations of LREE in the Esperança Basin associated with neoformed florencite(Ce). Lottermoser (1990) also identified a high concentration of phosphates at the interface between the carbonatite and the base of the lateritic profile, which cannot be accessed in the case of Morro dos Seis Lagos Deposit. Our data indicate that this interface may also be an HREE enrichment zone, which were leached along the entire studied profile, especially in the upper levels.

The Araxá Nb-deposit (Silva, 1986) is associated to a carbonate complex with $4.5 \mathrm{~km}$ in diameter, consisting of sovitos, beforsitos, and glimerites, where carbonatites occur as veins and dikes that cut the glimerites. The predominant carbonate is dolomite, with subordinate calcite and ankerite. Ba-pyrochlore, barite, phlogopite, apatite and magnetite occur as accessory minerals. The lateritic cover (thickness ranging from few meters to $230 \mathrm{~m}$ ) is composed of limonite, goethite, and magnetite, with minor chalcedony, Ba-pyrochlore and barite. Phosphorus released by apatite decomposition was deposited at the lower levels of the profile, in the form of neoformed apatite, or at the higher levels as phosphates of the crandalite and monazite group. The Morro dos Seis Lagos deposit differs in many respects: type and continuity of primary rock (siderite carbonatite only), mineralogy and textural complexity of laterite (hematite and goethite, 6 textural types), weathering intensity (much stronger, decomposition of pyrochlore, formation of $\mathrm{Nb}$-rich rutile, its transformation to $\mathrm{Nb}$ rich brookite and laterite reworking). 


\section{CONCLUSION}

The Morro dos Seis Lagos Nb (Ti, REE) deposit consists of a complex lateritic profile formed by the weathering of siderite carbonatite. This is the only type of carbonatite observed and has chemical and mineralogical characteristics compatible with a primary rock for the deposit.

The lateritic profile (>100 $\mathrm{m}$ in thickness) is formed by six textural and compositional types of laterite (from the surface downwards): (1) pisolitic laterite, (2) fragmented laterite, (3) mottled laterite, (4) purple laterite, (5) manganiferous laterite, and (6) brown laterite. All the laterites are mainly formed by goethite (predominant in the lower laterites) and hematite (predominant in the intermediary laterites). Goethite becomes more abundant again in the upper laterites as a result of reworking. In the manganiferous laterite (10 m thick), the manganese oxides (mainly hollandite, with associated cerianite) occur as veins formed in a late event during the development of the lateritic profile, precipitated from a solution with higher oxidation potential than that for Fe oxides, closer to the water. Siderite is the source for the Mn.

The $\mathrm{Nb}$-ore minerals are essentially $\mathrm{Nb}$-rich rutile with minor $\mathrm{Nb}$-rich brookite. $\mathrm{Nb}$ rich rutile occurs as isolated crystals in all laterites, with a composition 57.84 to 80.92 wt.\% $\mathrm{TiO}_{2}, 11.26$ to $22.23 \mathrm{wt} . \% \mathrm{Nb}_{2} \mathrm{O}_{5}$ and 8.96 to 14.95 wt. $\% \mathrm{Fe}_{2} \mathrm{O}_{3}$. Nb-rich brookite formed at the expense of $\mathrm{Nb}$-rich rutile, has similar composition to that of $\mathrm{Nb}$-rich rutile, occurs as spherules more commonly broken by collapsing of the laterites during the reworking of the upper laterites and has fine banded structure interpreted as Liesegang ring. $\mathrm{Nb}$-rich rutile and $\mathrm{Nb}$-rich brookite accommodate $\mathrm{Nb}$ following $\left[\mathrm{Fe}^{3+}+(\mathrm{Nb}, \mathrm{Ta})\right.$ for $\left.2 \mathrm{Ti}\right]$ substitution. The late mineral presents some deviation from the ideal substitution; the stage preceding its formation is represented by a breakdown of the structure in parts of the Nb-rich rutile crystals, with the formation of a gel in which the incipient formation of spherules can be seen.

The presence of $\mathrm{Nb}$-rich rutile rather than other common $\mathrm{Nb}$ minerals is related to the extremely intense lateritization. The primary pyrochlore was progressively weathered forming successive secondary pyrochlores until the Ce-pyrochlore that disappears in the upper part of the brown laterite. The formation of rutile Nb-rich, observed in the brown 
laterite, occurred, together with Ce-pyrochlore, $\mathrm{Nb}$-bearing goethite, and cerianite, from the alteration of a mineral presumably a former secondary pyrochlore.

The laterites have an average $\mathrm{Nb}_{2} \mathrm{O}_{5}$ content of 2.91 wt.\%. The $\mathrm{TiO}_{2}$ concentrations are significant as well, with an average of $5.00 \mathrm{wt} . \%$ in the upper laterites. The HREE were leached along the entire lateritic profile, especially in its upper part. The LREE were leached in the uppermost part of the profile, but were precipitated at the base of the reworked laterites (mottled laterite) and in the clays of the Esperança Basin as florencite-(Ce). Positive anomalies in Ce occur from upper purple crust to the base of the sequence. The analogy with Mount Weld deposit suggests that HREE and phosphate concentrations are likely to occur at lower deposit levels not accessed in the present study.

\section{ACKNOWLEDGMENTS}

The present work would not have been possible without the support given by the Companhia de Pesquisa de Recursos Minerais, through Roberto Ventura Santos, Eduardo Camozatto, and Renê Luzardo. Gert Rodolfo Woeltje (DNPM-Amazonas) is also thanked. The manuscript has benefitted from very constructive reviews by Roger Mitchell and Anton Chakhmouradian. The Conselho Nacional de Desenvolvimento Científico e Tecnológico CNPq is acknowledged for the financial support (projects 485415/2012-7 and 405839/20138).

\section{REFRENCES}

Almeida, M.E., Macambira, M.J.B., Faria, M.S.G. de, 2002. A granitogênese paleoproterozoica do sul de Roraima. In: Congresso Brasileiro de Geologia, 41, João Pessoa, 434.

Almeida, M.E., Macambira, M.J.B., Oliveira, E.C., 2007. Geochemistry and zircon geochronology of the I-type high-K calc-alkaline and S-type granitoid rocks from southeastern Roraima, Brazil: Orosirian collisional magmatism evidence (1.97-1.96 Ga) in central portion of Guyana Shield. Precambrian Research 155, 69-97. 
Anand, R.R., Butt, C.R.M, 1988. The terminology and classification of a deeply weathered regolith. CSIRO Division of Exploration Geoscience Discussion Paper.

Anand, R. R. \& Gilkes, R. J. 1984. Mineralogical and chemical properties of weathered magnetite grains from lateritic saprolite. Journal of Soil Science 35, 559-567.

Anand, R.R., Paine, M., 2002. Regolith geology of the Yilgarn Craton, Western Australia: implications for exploration. Australian Journal of Earth Sciences 49, 3-162.

Angélica, R.S.; Costa,M.L. 1993. Geochemistry of rare-earth elements in surface lateritic rocks and soils from the Maicuru complex, Para, Brazil. Jourrnal of geochemical Exploration, 47, 165-182.

Bonow, C.W., Issler R.S., 1980. Reavaliação e aspectos económicos do jazimento de terras raras e ferro-ligas do Lago Esperança, Complexo carbonatítico de Seis Lagos Amazonas, Brasil. In: Congresso Brasileiro de Geologia, 31, Camboriu, 3, 1431.

Buchanan, F. 1807. A Journey from Madras through the countries of Mysore, Canara and Malabar. East India Company, London, pp. 436-461.

Castellano, A., Melgarejo, J., Alfonso, P., Bambi, A.C.J.M., Alves, A.G.O.N., 2012. Subsolidus Processes in the Longonjo and Bailundo Carbonatites (Angola) 8-9.

Černý, P., Chapman, R., Simmons, W.B., Chackowsky, L.E., 1999. Niobian rutile from the McGuire granitic pegmatite, Park County, Colorado: Solid solution, exsolution, and oxidation. American Mineralogist 84, 754-763.

Chakhmouradian, A.R., 2006. High-field-strength elements in carbonatitic rocks: Geochemistry, crystal chemistry and significance for constraining the sources of carbonatites. Chemical Geology 235, 138-160.

Chakhmouradian, A.R., Reguir, E.P., Kressall, R.D., Crozier, J., Pisiak, L.K., Sidhu, R., Yang, P., 2015. Carbonatite-hosted niobium deposit at Aley, northern British Columbia (Canada): Mineralogy, geochemistry and petrogenesis. Ore Geology Reviews 64, 642666. 
Chakhmouradian, A.R., Zaitsev, A.N., 2012. Rare earth mineralization in igneous rocks: Sources and processes. Elements 8, 347-353.

Cordeiro, P.F. de O., Brod, J.A., Palmieri, M., de Oliveira, C.G., Barbosa, E.S.R., Santos, R.V., Gaspar, J.C., Assis, L.C., 2011. The Catalão I niobium deposit, central Brazil: Resources, geology and pyrochlore chemistry. Ore Geol. Rev. 41, 112-121.

Corrêa, S.L.A. 1996. Evolução geoquímica das crostas lateríticas e dos sedimentos sobrepostos na estrutura de Seis Lagos (Amazonas). PhD. thesis, Universidade Federal do Pará (in Portuguese).

Corrêa, S.L.A., Costa M.L., 1997. Mineralogia das crostas lateríticas ferruginosas de Seis Lagos (Amazonas). Geociências 16 (1), 141-156.

Costa, M.L.; Costa, J.A.V.; Angélica, R.S. 1993. Gold bearing bauxitic laterite in a Tropical rainforest climate. Cassiporé, Amapá, Brazil, Chron. Rec. Min. n 510, p. 41-51.

Costa, M.L. 1997. Lateritization as a major process of ore deposit formation in the Amazon region. Explor. Mining. Geol. 6 (1), 79-104.

CPRM, 2006. Geologia e recursos minerais do Estado do Amazonas. Map scale 1:1.000.000. Companhia de Pesquisa de Recursos Minerais, Manaus. CD-ROM (abstract in English).

Giovannini, A.L. 2013. Contribuição à geologia e geoquímica do carbonatito e da jazida (Nb, ETR) de Seis Lagos. Msc thesis Universidade Federal do Rio Grande do Sul (in Portuguese).

Gittins, J., Harmer, R.E., 1997. What is ferrocarbonatite? A revised classification. Journal of African Earth Sciences 25, 159-168.

Hirtopanu, P., Fairhurst, R.J., \& Jakab, G., 2015. Niobian rutile and its associations at Jolotca, Ditrau alkaline intrusive massif, East Carpathians. Geonomy 17(1), 39-55.

Issler, R.S., Silva, G.G. 1980. The seis lagos carbonatite complex. In: Congresso Brasileiro de Geologia 31, Camboriu, 3, 1564-1572. 
Justo, L.J.E.C., Souza, M.M., 1984. Jazida de nióbio do Morro dos Seis Lagos, Amazonas. In: Simpósio Amazonense 2, Manaus, 467-472.

Justo, L.J.E.C., Souza, M.M., 1986. Jazida de nióbio do Morro dos Seis Lagos, Amazonas. In. Schobbenhaus, C. and Coelho, C.E.S. (Eds), Principais Depósitos Minerais do Brasil - Ferro e Metais da Indústria do Aço. Departamento Nacional da Produção Mineral, 2, 463-468.

Krauskopf, K. B. 1985. Introduction to geochemistry. 2nd edition. Auckland, McGraw-Hill book Company. 617p.

Kravchenko, S.M., Pokrovsky, B.G., 1995. The Tomtor alkaline ultrabasic massif and related REE-Nb deposits, northern Siberia. Economic Geology 90, 676-689.

Krug, H.-J; Brandstädter, H.; Jacob, K. H. 1996. Morphological stabilities in pattern formation by precipitation and crystallization processes. Geologische Rundschau 85, 1928.

Lapin, A.V. and Kulikova, I.M., 1989. Processes of pyrochlore alteration and their products in the carbonatite weathering crusts. Zap. Vses. Mineral. Obshch., 118, (in Russian), 419.

Le Bas, M.J., 1981. Carbonatite magmas. Mineral. Mag. 44, 133-40.

Lottermoser, B.G., 1990. Rare-earth element mineralisation within the Mt. Weld carbonatite laterite, Western Australia. Lithos 24, 151-167.

Lottermoser, B.G., England, B.M., 1988. Compositional variation in pyrochlores from the Mount Weld carbonatite laterite, Western Australia. Mineralogy and Petrology 38, 3751.

Mariano, A.N., Mariano, A.Jr., 2012. Rare earth mining and exploration in North America. Elements 8, 369-375.

Mitchell, R.H., 2005. Carbonatites and carbonatites and carbonatites. Can. Mineral. 43, 2049-2068. 
Mitchell, R.H., 2015. Primary and secondary niobium mineral deposits associated with carbonatites. Ore Geology Reviews 64, 626-641.

Nahon, D., 1986. Evolution of iron crusts in tropical landscapes. In: Colman, S.M., Dethier, D.P. Eds. , Rates $\check{Z}$. of chemical weathering of rocks and minerals. Academic, London, 169-191.

Nahon, D., Tardy, Y., 1992. The ferruginous laterites. In: Butt, C.R.M. and Zeegers, H. (Eds.), Regolith exploration geochemistry in tropical and sub-tropical terrains. Handbook of Exploration Geochemistry 4, Elsevier, 41-55.

Ollier, C. D.; Galloway R., 1990. The laterite profile, ferricrete an unconformity. Catena, 17, 97-109.

Onuonga, I.O., Bowden, P., 2000. Hot-spring and supergene lanthanide mineralization at the Buru carbonatite centre, Western Kenya. Mineral. Mag. 64, 663-673.

Pasero, M., 2005. A Short Outline of the Tunnel Oxides. Rev. Mineral. Geochemistry 57.

Pereira, R.F., 2014. Nióbio. In: Sumário Mineral 2014. Departamento Nacional da Produção Mineral, Brasília, 94-95.

Pinheiro, S.S.; Fernandes, P. E. C. A.; Pereira, E. P.; Vasconcelos, E. G.; Pinto, A. C.; Montalvão, R. M. G.; Issler, R. S.; Dallagnoll, R.; Teixeira, W.; Fernandes, C. A. C. 1976. Folha NA.19 Pico da Neblina; geologia, geomorfologia, pedologia, vegetação e uso potencial da terra. Rio de Janeiro, Cap. 2, p.19-138. (Levantamento de Recursos Naturais)

Pirajno, F., Gonzalez-Alvarez, I., Chen, W., Kyser, K.T., Simonetti, A., Leduc, E., leGras, M., 2014. The Gifford Creek Ferrocarbonatite Complex, Gascoyne Province, Western Australia: Associated fenitic alteration and a putative link with the $\sim 1075 \mathrm{Ma}$ Warakurna LIP. Lithos 202-203, 100-119.

Porto C.G., Imbernon, R. A. L., Toleto, M. C. M., Menezes, R. O. G., Souza, J. J., Borges, C. E. P., 2010. Depósito de Cobre e Ouro em regolitos lateriticos no Brasil: casos de 
Chapada (GO) Igarapé Bahia e Salobo (Carajás, PA). (in, Modelos de depósitos de cobre no Brasil e sua resposta ao itemperismo. (eds)Brito, R. S. C., Silva, M. da G., Kuyumijan, R. M.), Brasília, CPRM, 189 - 213.

Porto, C.G., 2016. Geochemical exploration challenges in the regolith dominated Igarapé Bahia gold deposit, Carajás, Brazil. Ore Geology Reviews 73, 432 -450.

Rocha, E., Nasraoui, M., Soubiès, F., Bilal E., De Parseval, P., 2001. Évolution géochimique du pyrochlore au cours de l'altération météorique du gisement de Catalao II (Goiás, Brésil). Comptes Rendus l'Academie Sci. - Ser. IIa Sci. la Terre des Planetes 332, 9198.

Rossoni, M.B., Bastos Neto, A.C., Saldanha, D.L., Souza V.S., Giovannini, A.L., Porto, C.G., 2016. Aplicação de técnicas de sensoriamento remoto na investigação do controle do posicionamento do Complexo Carbonatítico Seis Lagos e no estudo do depósito $(\mathrm{Nb})$ laterítico associado (Amazonas, Brasil). Revista Pesquisas 43, 111-125.

Rudnick, R.L., Gao S., 2003. The composition of the continental crust. In: Treatise on Geochemistry - The Crust. In: Rudnick, R.L., Holland, H.D. and Turekian, K.K. (Eds.), Elsevier, Oxford, 1-64.

Santos, J.O.S., Hartmann, L.A., Gaudette, H.E., Groves, D.I., Mcnaughton, N.J., Fletcher, I.R., 2000. A New Understanding of the Provinces of the Amazon Craton Based on Integration of Field Mapping and $\mathrm{U}-\mathrm{Pb}$ and $\mathrm{Sm}-\mathrm{Nd}$ Geochronology. Gondwana Research 3, 453-488.

Santos, J.O.S., Potter, P.E., Reis, N.J., Hartmann, L.A, Fletcher, I.R., McNaughton, N.J., 2003. Age, source and Regional Stratigraphy of the Roraima Supergroup and Roraimalike Sequences in Northern South America, based on U-Pb Geochronology. Geological Society of America Bulletin 115 (3), 331-348.

Silva, A. B. da, 1986. Jazida de nióbio de Araxá, Minas Gerais. (in Principais depósitos minerais do Brasil. Vol. II, Shobbenhaus C., editor and Coelho C. E. da S., editor) DNPM, $435-453$. 
Simonetti, A., Bell, K., 1994. Isotopic and geochemical investigation of the Chilwa Island carbonatite complex, Malawi: evidence for a depleted mantle source region, liquid immiscibility, and open- system behaviour. Journal of Petrology 35, 1597-1621

Smith, D., 1984. On Ostwald's supersaturation theory of rhythmic precipitation (Liesegang's rings). Journal of Chemical Physics 81, 3102-3115.

Tardy, Y., Nahon, D., 1985. Geochemistry of laterites, stability of Al-goethite, Al-hematite, and $\mathrm{Fe}^{3+}$ kaolinites in bauxites and ferricretes: an approach to the mechanism of concretion formation. American Journal of Sciences 285, 865- 903.

Vasconcelos, P.M., Becker, T.A., Renne, P.R., Brimhall, G.H. 1994. Direct dating of weathering phenomena by $\mathrm{K}-\mathrm{Ar}$ and $40 \mathrm{Ar} / 39 \mathrm{Ar}$ analysis of supergene-Mn oxides. Geochim. Cosmochim. Acta 58:1635-65.

Verwoerd, W.J., Viljoen, E.A., Chevallier, L., 1995. Rare metal mineralization at the Salpeterkop carbonatite complex, Western Cape Province, South Africa. Journal of African Earth Sciences 21, 171-186.

Viegas Filho, J.R., Bonow, C.W., 1976. Projeto Seis Lagos (Internal Report). Companhia de Pesquisa de Recursos Minerais, Manaus.

Wall, F., Williams, C.T., Woolley, A.R., Nasraoui, M., 1996. Pyrochlore from weathered carbonatite at Lueshe, Zaire. Mineralogical Magazine 60, 731-750.

Walte,r J., 1915. Laterit in West Australien. Zeitschrift de Deutshens Geologischen Gesellchaft, 67B, 113-140.

Wells, M. A., Gilkes, R. J., Anand, R. R., 1989. The formation of corundum and aluminous hematite by the thermal dehydroxylation of aluminous goethite. Clay Minerals 24, 513530.

Woolley, A.R., Kjarsgaard, B.A., 2008. Paragenetic types of carbonatite as indicated by the diversity and relative abundances of associated silicate rocks: Evidence from a global database. Canadian Mineralogist 46, 741-752. 
Zaitsev, A. N., Sitnikova, M. A., Subbotin, V. V., Fernandez-Suarez J., Jeffries T. E.. 2004. Sallanlatvi Complex; a rare example of magnesite and siderite carbonatites (in Phoscorites and carbonatites from mantle to mine; the key example of the Kola alkaline province, (eds) Wall F., Zaitsev A. N.) Mineralogical Society Series 10: 201-246.

\section{FIGURES CAPTIONS}

Fig. 1. Location and geological map of the Morro dos Seis Lagos deposit (Viegas e Bonow, 1976).

(2 columns)

Fig. 2. Digital terrain model of the Morro dos Seis Lagos Carbonatite Body (Rossoni et al. 2016), whose lateritic cover corresponds to the Morro dos Seis Lagos deposit. N-S, NW and NE morphostructures correspond to faults that control the relief on the deposit. The E-W structure controlled the positioning of the carbonatite body; it was reactivated and affected the southern part of the deposit, where it controls a series of depressions filled by sediments (see Fig. 1).

(2 columns)

Fig. 3. (A) Dragon lake (located in Fig. 1B) formed in the laterite. (B) Malaquita lake formed in the talus zone, seen from the top of the laterite; on the third plane is observed the plain formed by the basement. (C) Outcroup of laterite with Mn-oxides, near Dragon lake. (D) Laterite with vertical cavities interpreted as ancient pedoturbation, near Dragon lake.

(2 columns)

Fig. 4. Microscopic features of the carbonatite and laterites of the Morro dos Seis Lagos deposit. (A) Typical border siderite carbonatite formed by siderite crystals cut by hematite and the matrix formed of aggregates of barite crystals and aggregates (dark zones) of 
gorceixite, monazite and pyrochlore (PL). (B) BSE image of border siderite carbonatite formed by siderite crystals with monazite rich zones and matrix formed by aggregate rich in gorceixite, cut by a barite vein. (C) Core siderite carbonatite with siderite, pyrochlore euhedral crystals and gibbsite veilets (BSE image). (D) Core siderite carbonatite with siderite crystals within a hematitic matrix with relicts of siderite and thorbastnäsite filling spaces in the matrix (EDS image).: (E) Fibrous goethite filling tubular cavities and as pisolites, darker red Fe-bands are more hematitic (pisolitic laterite). (F) Sub-rounded Fe fragment set in porous matrix, where Fe precipitates in irregular masses and bands, with specks of Nb-rich rutile (fragmented laterite). (G) Fibrous goethite growing over darker red Fe hematitic bands around fragments formed by massive goethite (fragmented laterite). $(\mathrm{H})$ Zoned $\mathrm{Nb}$-rich rutile crystal (fragmented laterite). (I) Specks of Nb-rich rutile grains immersed in a banded ferruginous fragment (fragmented laterite). (J) Zoned and fractured Nb-rich rutile crystals set in a ferruginous cavity (mottled laterite). (K) Early goethite (Gth1) and late goethite (Gth2) (purple laterite); (L) Spherules of $\mathrm{Nb}$-rich brookite (purple laterite). Abbreviations: Sid (siderite), Bar (barite), Mon (monazite), Gor (gorceixite), Aggr. (aggregates), Hmt (hematite), Gth (goethite), Rt (Nb-rich rutile), Brk (Nb-rich brookite).

(2 columns)

Fig. 5. Seis Lagos siderite carbonatite classification (modified from Gittins and Harmer, 1997). Other ferrocarbonatites: Sallanlatvi (Zaitzev et. al. 2004); Swartbooisdrif (Thompson et. al 2002); Chilwa (Simoneti and Bell, 1994); Buru \& Kuge (Onwonga, 1997), Le Bas (1981), other data from Gittins and Harmer, 1997.

(1 column)

Fig. 6. Distribution of the different types of laterite and studied samples in drill hole SG-01AM.

(1 column) 
Fig. 7. (A) Zoned crystal of Nb-rich rutile from fragmented laterite with edge turned into gel (Min 1) in which there is the incipient formation of spherules. (B) Spherules of Min 2 (Fe$\mathrm{Nb}$-rich brookite?) in $\mathrm{Nb}$-rich rutile from mottled laterite.

Fig. 8. SEM images and photomicrographys. (A) Nb-rich rutile with spherules of Min2 (Nbrich brookite?) (mottled laterite). (B) Columbite as a relict mineral in goethite (mottled laterite). (C) Veinlets of unidentified mineral rich in $\mathrm{Fe}$ and $\mathrm{Nb}$ (motled laterite). (D) Zoned $\mathrm{Nb}$-rich brookite spherule (purple laterite). (E) Banded Mn-rich veins constituted of hollandite, pyrolusite, cerianite and Mn-bearing goethite (manganiferous laterite). (F) Fibrous growing front of hollandite (Mn laterite). (G) Hollandite and cerianite intergrow (Mn laterite). (H) Typical microscopic texture formed by botryoidal goethite evenly distributed (brown laterite). (I) Pyrochlore small crystals with core transformed to goethite (brown laterite). Abbreviations: Gth (goethite), Min2 (non-identified mineral, possibly Nb-rich brookite), Hol (holandite), Cer (cerianite), Pir (pyrolusite), Pcl (pyrochlore), Clb (columbite), $\mathrm{Rt}(\mathrm{Nb}$-rich rutile).

(2 columns)

Fig. 9. (A) Former mineral (white area) transformed into smaller crystals of secondary Nbrich rutile, Ce-pyrochlore and $\mathrm{Nb}$-bearing goethite. (B) Euhedral $\mathrm{Nb}$-rich rutile in association with a deeply weathered Ce-pyrochlore.

( 2 columns)

Fig. 10. Vertical distribution of (A) hematite and goethite, (B) $\mathrm{Fe}_{2} \mathrm{O}_{3}, \mathrm{MnO}$ and LOI, (C) $\mathrm{TiO}_{2}, \mathrm{Nb}_{2} \mathrm{O}_{5}, \mathrm{WO}_{3}$ and $\mathrm{TiO}_{2} / \mathrm{Nb}_{2} \mathrm{O}_{5}$ and (D) $\mathrm{P}_{2} \mathrm{O}_{5}, \mathrm{Al}_{2} \mathrm{O}_{3}$ ans $\mathrm{SiO}_{2}$ in laterites from the Morro dos Seis Lagos deposit.

(2 columns) 
Fig. 11. Binary diagrams for Fe oxides. Al vs Fe. (1) Fragmented laterite; (2) mottled laterite;

(3) upper purple laterite; (4) goethite from Mn-rich veins in manganiferous laterite.

( 1 column)

Fig. 12. Binary diagrams for $\mathrm{Nb}$-rich rutile, $\mathrm{Nb}$-rich brookite, and Min 2 (see text). (A) FeO (wt.\%) vs $\mathrm{Nb}_{2} \mathrm{O}_{5}$ (wt.\%). (B) $\mathrm{Ti}$ vs $\mathrm{Nb}+\mathrm{Fe}^{3+}$. (A): Nb-rich brookite; (B) Nb-rich rutile (isolated crystals all laterites); (C): Min 2; (D): Nb-rich rutile associated with Ce-pyrochlore. ( 1 column)

Fig. 13. Binary diagram Ce (apfu) vs Vacancy (apfu) showing progressive weathering of Cepyrochlore from brown laterite.

(1 column)

Fig. 14. Rare earth element patterns in the Morro dos Seis Lagos deposit. Normalized to chondrite C1 (McDonough and Sun 1995).

(2 columns) 
Table 1. Representative compositions of siderite carbonatite from the Morro dos Seis Lagos carbonatite body. Samples 02 are from the borehole SG-02-AM (border); samples 04 are from the borehole SG-04-AM (core).

\begin{tabular}{|c|c|c|c|c|c|c|c|c|c|}
\hline & \multicolumn{3}{|c|}{ Border } & \multicolumn{6}{|c|}{ Core } \\
\hline$\%$ & $02-53 \mathrm{C}$ & $02-54 \mathrm{~A}$ & 02-54B & $04-59$ & $04-72$ & $04-76$ & $04-81$ & 04-19 & $04-92$ \\
\hline $\mathrm{SiO}_{2}$ & 0.38 & 0.32 & 0.36 & 0.77 & 1.29 & 0.26 & 0.12 & 0.48 & 0.08 \\
\hline $\mathrm{Al}_{2} \mathrm{O}_{3}$ & 1.34 & 0.92 & 1.34 & 0.45 & 1.85 & 1.1 & 1.05 & 0.27 & 0.33 \\
\hline $\mathrm{Fe}_{2} \mathrm{O}_{3}$ & 51.27 & 55.93 & 48.64 & 70.85 & 63.06 & 67.24 & 66.99 & 66.89 & 68.18 \\
\hline $\mathrm{MgO}$ & 3.20 & 2.75 & 3.20 & 1.72 & 0.99 & 2.10 & 2.08 & 1.44 & 0.99 \\
\hline $\mathrm{CaO}$ & 0.30 & 0.14 & 0.21 & 0.31 & 0.82 & 0.64 & 0.47 & 0.38 & 0.36 \\
\hline $\mathrm{Na}_{2} \mathrm{O}$ & 0.01 & $<0.01$ & $<0.01$ & 0.03 & 0.16 & 0.09 & 0.07 & 0.12 & 0.08 \\
\hline $\mathrm{K}_{2} \mathrm{O}$ & 0.05 & 0.03 & 0.05 & 0.12 & $<0.01$ & 0.06 & 0.08 & 0.11 & 0.08 \\
\hline $\mathrm{TiO}_{2}$ & 0.16 & 0.17 & 0.17 & 0.10 & 0.83 & 1.28 & 1.60 & 5.28 & 4.11 \\
\hline $\mathrm{P}_{2} \mathrm{O}_{5}$ & 2.01 & 0.81 & 1.56 & 0.13 & 0.87 & 0.28 & 0.27 & 0.23 & 0.14 \\
\hline $\mathrm{MnO}$ & 6.73 & 11.69 & 5.10 & 2.14 & 2.18 & 2.06 & 2.39 & 1.87 & 1.49 \\
\hline LOI & 24.60 & 22.80 & 25.20 & 22.40 & 24.30 & 21.80 & 22.30 & 20.00 & 21.10 \\
\hline Sum & 90.08 & 95.56 & 85.81 & 99.01 & 96.49 & 97.02 & 97.48 & 97.33 & 97.08 \\
\hline \multicolumn{10}{|l|}{ ppm } \\
\hline $\mathrm{Nb}$ & 2291.6 & 1102.8 & 1532.7 & 636.3 & 3240.4 & 6431.9 & 6288.9 & 6152.2 & 7667.4 \\
\hline $\mathrm{Ta}$ & 0.2 & 0.2 & 1 & 0.4 & 2.3 & 1.8 & 1.5 & 1.3 & 1.9 \\
\hline $\mathrm{La}$ & 783.4 & 183.5 & 483.8 & 142.2 & 3795.2 & 1775.4 & 930.9 & 265.7 & 281 \\
\hline $\mathrm{Ce}$ & 4604.8 & 2986.5 & 2875.2 & 574.6 & 7450.3 & 3625.5 & 1968.7 & 848.5 & 708.6 \\
\hline $\operatorname{Pr}$ & 884.59 & 134.12 & 627.73 & 114.69 & 847.98 & 444.96 & 281.9 & 155.58 & 111.17 \\
\hline $\mathrm{Nd}$ & 4662.4 & 709.8 & 3093.5 & 709.1 & 3205.4 & 2032.1 & 1578.1 & 1270.4 & 870.9 \\
\hline $\mathrm{Sm}$ & 913.55 & 139.51 & 467.91 & 203.83 & 573.24 & 548.58 & 536.7 & 705.8 & 851.88 \\
\hline $\mathrm{Eu}$ & 225.44 & 34.18 & 110.68 & 49.03 & 132.95 & 132.35 & 117.65 & 172.56 & 203.03 \\
\hline $\mathrm{Gd}$ & 524.8 & 79.45 & 277 & 129.15 & 293.19 & 277.02 & 225.38 & 298.46 & 320.32 \\
\hline $\mathrm{Tb}$ & 79.99 & 10.32 & 41.21 & 9.18 & 26.21 & 22.07 & 17.72 & 20.2 & 19.46 \\
\hline Dy & 362.69 & 46.01 & 186.36 & 32.21 & 101.4 & 76.86 & 63.14 & 71.73 & 60.15 \\
\hline Ho & 56.9 & 7.21 & 29.04 & 3.73 & 11.99 & 8.52 & 6.48 & 7.34 & 3.97 \\
\hline $\mathrm{Er}$ & 117.23 & 17.8 & 59.77 & 8.15 & 27.39 & 18.02 & 14.53 & 17.05 & 9.97 \\
\hline $\mathrm{Tm}$ & 14.26 & 2.2 & 7.07 & 1.02 & 3.42 & 2.3 & 1.97 & 2.52 & 1.79 \\
\hline $\mathrm{Yb}$ & 73.58 & 12.44 & 35.98 & 6.55 & 19.86 & 13.81 & 12.78 & 16.12 & 11.89 \\
\hline $\mathrm{Lu}$ & 8.99 & 1.58 & 4.54 & 0.79 & 2.43 & 1.67 & 1.44 & 1.94 & 1.33 \\
\hline $\mathrm{Y}$ & 1292.2 & 196.2 & 696 & 143.7 & 470.4 & 392.9 & 325.8 & 615.1 & 375.1 \\
\hline $\mathrm{Sc}$ & 183 & 131 & 113 & 265 & 865 & 847 & 695 & 1590 & 1095 \\
\hline $\mathrm{Rb}$ & 1.2 & 0.6 & 0.8 & 1.2 & 0.5 & 2.6 & 5.6 & 6.6 & 3.4 \\
\hline $\mathrm{Ba}$ & $>50000$ & 28673 & $>50000$ & 1434 & 2743 & 2607 & 1928 & 1481 & 1485 \\
\hline $\mathrm{Sr}$ & 982.2 & 475.3 & 1028.3 & 45.6 & 554.6 & 282.3 & 212.4 & 87 & 86.9 \\
\hline $\mathrm{Pb}$ & 1084.8 & 394.2 & 873.3 & 107.3 & 296.1 & 112.4 & 107.9 & 55.8 & 232.3 \\
\hline $\mathrm{Th}$ & 1736.6 & 538.1 & 954.1 & 1895.5 & 3059.9 & 2578.8 & 2807.7 & 5223 & 5973.3 \\
\hline $\mathrm{U}$ & 2.3 & 0.6 & 1.6 & 0.2 & 2.6 & 1 & 1 & 0.9 & 1.2 \\
\hline $\mathrm{Zr}$ & 142.9 & 102 & 145.1 & 155.2 & 140 & 103.5 & 58.6 & 32.6 & 34.3 \\
\hline $\mathrm{Hf}$ & 3.3 & 2.4 & 3.6 & 4.7 & 2 & 2.3 & 1.1 & 0.8 & 0.5 \\
\hline $\mathrm{Co}$ & 25.7 & 41.9 & 18.5 & 59.9 & 64.7 & 55.6 & 58.3 & 73 & 69.8 \\
\hline $\mathrm{V}$ & 243 & 192 & 325 & 64 & 263 & 143 & 134 & 179 & 147 \\
\hline W & 8.6 & 8.1 & 11.2 & 8.3 & 38 & 63.9 & 65.8 & 230 & 159.3 \\
\hline $\mathrm{Zn}$ & 1268 & 1682 & 1242 & 1254 & 1194 & 1513 & 1780 & 2296 & 2999 \\
\hline $\mathrm{Cu}$ & 1.8 & 3.6 & 1.4 & 0.4 & 7.5 & 1.4 & 1.2 & 1.6 & 1.1 \\
\hline $\mathrm{F}$ & 940 & 610 & 1030 & 269 & 156 & 449 & 476 & n.a. & 156 \\
\hline
\end{tabular}


Table 2. Representative compositions and structural formulae of Fe oxides from the Morro dos Seis Lagos deposit. Samples from borehole SG-01-AM (Fig. 6): fragmented crust (sample 04), mottled crust (sample 06), upper purple crust (sample 12), manganiferous crust (sample 15) and brown crust (samples 27 and 31).

\begin{tabular}{|c|c|c|c|c|c|c|c|c|c|c|}
\hline \multirow[b]{2}{*}{ Crust } & 04.1 & 04.2 & 06.1 & 06.2 & 12.1 & 12.2 & 15.1 & 15.2 & 27.1 & 31.1 \\
\hline & \multicolumn{2}{|c|}{ Fragmented } & \multicolumn{2}{|c|}{ Mottled } & \multicolumn{2}{|c|}{ Upper Purple } & \multicolumn{2}{|c|}{ Manganiferous } & \multicolumn{2}{|c|}{ Brown } \\
\hline $\mathrm{Fe}_{2} \mathrm{O}_{3}$ & 86.86 & 90.68 & 90.92 & 91.12 & 94.10 & 98.71 & 86.08 & 85.48 & 90.74 & 80.90 \\
\hline $\mathrm{Al}_{2} \mathrm{O}_{3}$ & 1.30 & n.d. & 0.34 & 0.07 & 0.21 & 0.05 & 0.15 & 0.20 & 0.06 & 0.13 \\
\hline $\mathrm{SiO}_{2}$ & 0.10 & 0.69 & 0.08 & 0.08 & 0.20 & 0.08 & 0.53 & 0.44 & 0.35 & 0.80 \\
\hline $\mathrm{MnO}_{2}$ & 0.22 & n.d. & n.d. & n.d. & 0.52 & 0.12 & 2.03 & 2.26 & n.d. & n.d. \\
\hline $\mathrm{TiO}_{2}$ & 0.10 & 0.09 & 0.11 & 0.02 & n.d. & n.d. & n.d. & n.d. & 1.53 & 0.16 \\
\hline $\mathrm{Nb}_{2} \mathrm{O}_{5}$ & 0.16 & 0.01 & n.d. & 0.04 & 0.05 & n.d. & n.d. & n.d. & 3.19 & 0.25 \\
\hline Total & 88.74 & 91.47 & 91.45 & 91.33 & 95.08 & 98.96 & 88.79 & 88.38 & 95.87 & 82.24 \\
\hline \multicolumn{11}{|c|}{ Structural Formulae } \\
\hline $\mathrm{Fe}^{3+}$ & 1.936 & 1.958 & 1.981 & 1.992 & 1.968 & 1.991 & 1.908 & 1.905 & 1.871 & 1.933 \\
\hline $\mathrm{Al}$ & 0.045 & & 0.012 & 0.002 & 0.007 & 0.002 & 0.005 & 0.007 & 0.002 & 0.005 \\
\hline $\mathrm{Si}$ & 0.004 & 0.030 & 0.003 & 0.003 & 0.008 & 0.003 & 0.023 & 0.020 & 0.014 & 0.038 \\
\hline $\mathrm{Mn}^{4+}$ & 0.005 & & & & 0.010 & 0.002 & 0.041 & 0.046 & & \\
\hline $\mathrm{Ti}$ & 0.002 & 0.002 & 0.002 & 0.000 & & & & & 0.032 & 0.004 \\
\hline $\mathrm{Nb}$ & 0.002 & 0.000 & & 0.001 & 0.001 & & & & 0.040 & 0.004 \\
\hline Total & 1.994 & 1.990 & 1.998 & 1.998 & 1.994 & 1.998 & 1.977 & 1.978 & 1.959 & 1.984 \\
\hline
\end{tabular}

Atoms per formula unit calculated on the basis of 3 oxygens.

Table 3. Representative compositions and structural formulae of hollandite from manganiferous crust from the Morro dos Seis Lagos deposit. Samples located in borehole SG-01-AM (Fig. 6).

\begin{tabular}{|c|c|c|c|c|c|c|c|c|}
\hline & 13.01 & 13.02 & 15.01 & 15.02 & 15.03 & 15.04 & 15.05 & 17.01 \\
\hline $\mathrm{K} 2 \mathrm{O}$ & 0.07 & 0.05 & 0.01 & 0.11 & 0.07 & 0.08 & 0.16 & 0.19 \\
\hline $\mathrm{BaO}$ & 17.22 & 14.66 & 17.59 & 16.88 & 16.43 & 15.94 & 16.52 & 14.62 \\
\hline $\mathrm{PbO}$ & 0.03 & 0.20 & n.d. & 0.04 & n.d. & n.d. & n.d. & 0.13 \\
\hline $\mathrm{MnO}$ & 6.46 & 6.50 & 2.72 & 7.15 & 7.05 & 6.53 & 7.35 & 6.66 \\
\hline $\mathrm{MnO} 2$ & 70.99 & 75.89 & 67.47 & 73.24 & 73.30 & 73.73 & 73.51 & 75.74 \\
\hline $\mathrm{Al} 2 \mathrm{O} 3$ & 1.10 & 0.43 & 2.22 & 0.72 & 0.46 & 0.50 & 0.40 & 0.17 \\
\hline $\mathrm{Fe} 2 \mathrm{O} 3$ & 1.82 & 0.18 & 8.72 & 0.58 & 0.62 & 1.24 & 0.31 & 0.38 \\
\hline Total & 97.69 & 97.91 & 98.73 & 98.72 & 97.93 & 98.02 & 98.24 & 97.89 \\
\hline \multicolumn{9}{|c|}{ Structural Formulae } \\
\hline $\mathrm{Mn} 2$ & 0.758 & 0.740 & 0.317 & 0.824 & 0.823 & 0.756 & 0.848 & 0.751 \\
\hline Mn4 & 6.870 & 7.172 & 6.419 & 6.998 & 7.037 & 7.034 & 7.055 & 7.183 \\
\hline $\mathrm{Al}$ & 0.181 & 0.069 & 0.360 & 0.118 & 0.076 & 0.081 & 0.065 & 0.027 \\
\hline $\mathrm{Fe}$ & 0.192 & 0.019 & 0.904 & 0.060 & 0.064 & 0.129 & 0.032 & 0.039 \\
\hline$\Sigma \mathrm{B}$ & 8.000 & 8.000 & 8.000 & 8.000 & 8.000 & 8.000 & 8.000 & 8.000 \\
\hline $\mathrm{K}$ & 0.013 & 0.009 & 0.001 & 0.020 & 0.012 & 0.014 & 0.028 & 0.033 \\
\hline $\mathrm{Ba}$ & 0.944 & 0.784 & 0.949 & 0.913 & 0.893 & 0.861 & 0.897 & 0.784 \\
\hline $\mathrm{Pb}$ & 0.001 & 0.007 & & 0.002 & & & & 0.005 \\
\hline$\Sigma \mathrm{A}$ & 0.958 & 0.800 & 0.950 & 0.935 & 0.905 & 0.875 & 0.925 & 0.822 \\
\hline
\end{tabular}

n.d.= not detected $\mathrm{Mn}^{2+} / \mathrm{Mn}^{4+}$ and analysis totals calculated on a basis of stoichiometry $(\Sigma \mathrm{B}=8 ; \mathrm{O}=16)$ 
Table 4. Representative compositions and structural formulae of Nb-rich rutile from the borehole SG-10-AM (Fig. 6) from the Morro dos Seis Lagos deposit: fragmented crust (sample 4), mottled crust (5 crystals in sample 6) and upper purple crust (sample 12) and brown crust (5 crystals in sample 34).

\begin{tabular}{|c|c|c|c|c|c|c|c|c|c|c|c|c|}
\hline \multicolumn{8}{|c|}{$\mathrm{Nb}$-rich rutile } & \multicolumn{5}{|c|}{ Nb-rich rutile (brown crust) } \\
\hline & 4.1 & 6.1 & 6.2 & 6.3 & 6.4 & 6.5 & 12.1 & 34.1 & 34.2 & 34.3 & 34.4 & 34.5 \\
\hline $\mathrm{Fe}_{2} \mathrm{O}_{3}$ & 8.96 & 12.18 & 13.94 & 11.12 & 14.95 & 10.52 & 17.78 & 14.92 & 11.64 & 11.67 & 11.18 & 12.43 \\
\hline $\mathrm{SiO}_{2}$ & n.d. & 1.09 & 0.45 & 0.63 & 0.62 & 0.52 & 1.00 & 0.33 & 0.27 & 0.34 & 0.30 & 0.28 \\
\hline $\mathrm{TiO}_{2}$ & 80.92 & 70.73 & 68.92 & 72.45 & 66.26 & 74.08 & 57.84 & 58.26 & 67.34 & 68.66 & 66.92 & 57.86 \\
\hline $\mathrm{Nb}_{2} \mathrm{O}_{5}$ & 11.26 & 16.59 & 19.08 & 16.71 & 18.89 & 14.89 & 22.23 & 25.46 & 19.16 & 17.47 & 20.28 & 27.61 \\
\hline $\mathrm{WO}_{3}$ & 0.16 & 0.35 & 0.31 & 0.70 & 0.33 & 0.64 & 1.27 & 0.20 & 0.33 & 0.19 & 0.85 & 0.62 \\
\hline Total & 101.30 & 100.94 & 102.70 & 101.61 & 101.05 & 100.65 & 100.12 & 99.17 & 98.74 & 98.33 & 99.53 & 98.80 \\
\hline \multicolumn{13}{|c|}{ Structural Formulae } \\
\hline $\mathrm{Fe}^{3+}$ & 0.093 & 0.130 & 0.148 & 0.118 & 0.162 & 0.112 & 0.198 & 0.168 & 0.128 & 0.128 & 0.123 & 0.140 \\
\hline $\mathrm{Si}$ & & 0.015 & 0.006 & 0.009 & 0.009 & 0.007 & 0.015 & 0.005 & 0.004 & 0.005 & 0.004 & 0.004 \\
\hline $\mathrm{Ti}$ & 0.841 & 0.753 & 0.729 & 0.766 & 0.715 & 0.786 & 0.643 & 0.653 & 0.740 & 0.754 & 0.732 & 0.653 \\
\hline $\mathrm{Nb}$ & 0.070 & 0.106 & 0.122 & 0.106 & 0.123 & 0.095 & 0.149 & 0.172 & 0.127 & 0.115 & 0.134 & 0.187 \\
\hline $\mathrm{W}$ & 0.001 & 0.001 & 0.001 & 0.003 & 0.001 & 0.002 & 0.005 & 0.001 & 0.001 & 0.001 & 0.003 & 0.002 \\
\hline Cations & 1.005 & 1.005 & 1.006 & 1.002 & 1.010 & 1.002 & 1.010 & 0.999 & 1.000 & 1.003 & 0.996 & 0.986 \\
\hline
\end{tabular}

n.d.= not detected; Atoms per formula unit calculated on the basis of two oxigens.

Table 5. Representative compositions and structural formulae of Nb-rich brookite from the upper purple crust from the Morro dos Seis Lagos deposit. Samples from borehole SG-01-AM (Fig. 6): 2 crystals in sample 10; 2 crystals in sample 12 .

\begin{tabular}{cccccc}
\hline \multicolumn{5}{c}{ Nb-rich brookite } \\
\hline $\mathrm{Fe}_{2} \mathrm{O}_{3}$ & 10.1 & 10.2 & 10.3 & 12.1 & 12.2 \\
$\mathrm{SiO}_{2}$ & 0.97 & 1.24 & 0.64 & 0.72 & 0.78 \\
$\mathrm{TiO}_{2}$ & 69.60 & 73.45 & 76.68 & 76.93 & 78.02 \\
$\mathrm{Nb}_{2} \mathrm{O}_{5}$ & 16.03 & 12.09 & 11.77 & 10.75 & 10.43 \\
$\mathrm{WO}_{3}$ & 0.69 & 0.32 & 0.74 & 1.10 & 0.80 \\
$\mathrm{Total}$ & 99.37 & 99.63 & 99.69 & 100.39 & 100.72 \\
\hline Structural Formulae & & & & \\
\hline $\mathrm{Fe}$ & 0.131 & 0.134 & 0.105 & 0.115 & 0.112 \\
$\mathrm{Si}$ & 0.014 & 0.018 & 0.009 & 0.010 & 0.011 \\
$\mathrm{Ti}$ & 0.753 & 0.783 & 0.814 & 0.812 & 0.818 \\
$\mathrm{Nb}$ & 0.104 & 0.078 & 0.075 & 0.068 & 0.066 \\
$\mathrm{~W}$ & 0.003 & 0.001 & 0.003 & 0.004 & 0.003 \\
$\mathrm{Cations}$ & 1.005 & 1.014 & 1.006 & 1.009 & 1.010 \\
\hline
\end{tabular}

Atoms per formula unit calculated on the basis of two oxigens. 
Table 6. Representative compositions of Ce-pyrochlore from the brown crust from the Morro dos Seis Lagos deposit.

\begin{tabular}{|c|c|c|c|c|c|c|c|c|c|c|}
\hline & \multicolumn{4}{|c|}{ SG-01-AM-27 } & \multicolumn{2}{|c|}{ SG-01-AM-31 } & \multicolumn{4}{|c|}{ SG-01-AM-34 } \\
\hline & 1 & 2 & 3 & 4 & 1 & 2 & 1 & 2 & 3 & 4 \\
\hline $\mathrm{Na}_{2} \mathrm{O}$ & 0.05 & 0.02 & 0.02 & 0.27 & 0.37 & 0.68 & 0.04 & 0.13 & 1.67 & 1.01 \\
\hline $\mathrm{K}_{2} \mathrm{O}$ & 0.03 & 0.02 & 0.00 & 0.04 & 0.03 & 0.12 & 0.02 & 0.03 & 0.08 & 0.16 \\
\hline $\mathrm{BaO}$ & 4.03 & 2.05 & 0.57 & 3.60 & 4.61 & 4.47 & 0.18 & 1.73 & 3.10 & 1.47 \\
\hline $\mathrm{PbO}$ & 1.55 & 8.33 & 11.36 & 1.50 & 8.13 & 8.09 & 1.40 & 8.99 & 6.13 & 4.66 \\
\hline $\mathrm{SrO}$ & 0.07 & 0.03 & n.d. & 0.11 & 0.17 & 0.04 & 0.01 & n.d. & 0.03 & 0.02 \\
\hline $\mathrm{CaO}$ & 0.16 & 0.35 & n.d. & 0.65 & 0.62 & 0.14 & 0.22 & n.d. & n.d. & n.d. \\
\hline $\mathrm{MnO}$ & 0.00 & 0.11 & 0.03 & 0.07 & 0.14 & 0.22 & 0.00 & 0.10 & 0.04 & n.d. \\
\hline $\mathrm{La}_{2} \mathrm{O}_{3}$ & 6.92 & 6.13 & 1.79 & 6.41 & 4.41 & 3.81 & 0.41 & 1.73 & 2.66 & 2.20 \\
\hline $\mathrm{Ce}_{2} \mathrm{O}_{3}$ & 12.43 & 18.92 & 24.13 & 12.16 & 15.63 & 15.66 & 28.25 & 17.28 & 21.48 & 23.36 \\
\hline $\mathrm{Pr}_{2} \mathrm{O}_{3}$ & 1.92 & 2.59 & 0.33 & 1.97 & 1.10 & 1.13 & 0.08 & 0.77 & 0.55 & 0.98 \\
\hline $\mathrm{Nd}_{2} \mathrm{O}_{3}$ & 3.26 & 3.66 & 0.34 & 3.25 & 1.74 & 1.40 & 0.31 & 1.48 & 1.37 & 2.35 \\
\hline $\mathrm{Sm}_{2} \mathrm{O}_{3}$ & 0.19 & 0.05 & n.d. & 0.21 & 0.17 & 0.13 & 0.03 & 0.04 & 0.07 & 0.07 \\
\hline $\mathrm{Eu}_{2} \mathrm{O}_{3}$ & 0.24 & 0.04 & 0.06 & 0.35 & 0.17 & 0.16 & 0.04 & 0.08 & 0.06 & 0.23 \\
\hline $\mathrm{Gd}_{2} \mathrm{O}_{3}$ & 0.02 & 0.25 & 0.35 & 0.08 & 0.32 & 0.32 & 0.57 & 0.30 & 0.27 & 0.42 \\
\hline $\mathrm{Dy}_{2} \mathrm{O}_{3}$ & 0.00 & 0.02 & n.d. & n.d. & n.d. & 0.02 & 0.00 & 0.14 & n.d. & n.d. \\
\hline $\mathrm{Er}_{2} \mathrm{O}_{3}$ & 0.11 & 0.03 & 0.09 & 0.01 & 0.01 & 0.04 & 0.05 & 0.12 & n.d. & n.d. \\
\hline $\mathrm{Y}_{2} \mathrm{O}_{3}$ & 0.57 & 0.12 & 0.02 & 0.46 & 0.14 & 0.32 & 0.03 & 0.62 & 1.56 & 0.22 \\
\hline $\mathrm{ThO}_{2}$ & 0.29 & 0.38 & 0.40 & 0.15 & 1.16 & 1.05 & 13.76 & 3.80 & 0.90 & 2.55 \\
\hline $\mathrm{Fe}_{2} \mathrm{O}_{3}$ & 1.71 & 3.11 & 3.50 & 2.61 & 1.27 & 2.59 & 2.59 & 1.53 & 1.35 & 2.23 \\
\hline $\mathrm{Al}_{2} \mathrm{O}_{3}$ & 0.02 & 0.13 & 0.05 & 0.17 & 0.10 & 0.06 & 0.06 & 0.15 & 0.01 & 0.10 \\
\hline $\mathrm{TiO}_{2}$ & 8.91 & 4.41 & 2.61 & 9.16 & 4.82 & 6.39 & 2.72 & 8.43 & 7.86 & 4.89 \\
\hline $\mathrm{SiO}_{2}$ & 0.07 & 0.18 & 0.10 & 0.11 & 2.85 & 4.54 & 0.31 & 3.30 & 1.62 & 0.91 \\
\hline $\mathrm{Nb}_{2} \mathrm{O}_{5}$ & 49.35 & 49.04 & 51.46 & 46.76 & 45.93 & 44.27 & 35.27 & 40.03 & 43.25 & 39.66 \\
\hline $\mathrm{Ta}_{2} \mathrm{O}_{5}$ & 0.01 & n.d. & 0.01 & n.d. & n.d. & 0.16 & n.d. & n.d. & n.d. & n.d. \\
\hline Sum & 91.91 & 99.97 & 97.22 & 90.10 & 93.89 & 95.81 & 86.35 & 90.78 & 94.06 & 87.49 \\
\hline \multicolumn{11}{|c|}{ Structural Formula } \\
\hline $\mathrm{Na}$ & 0.006 & 0.003 & 0.003 & 0.035 & 0.051 & 0.084 & 0.008 & 0.017 & 0.230 & 0.161 \\
\hline $\mathrm{K}$ & 0.003 & 0.002 & 0.000 & 0.003 & 0.003 & 0.010 & 0.003 & 0.003 & 0.007 & 0.017 \\
\hline $\mathrm{Ba}$ & 0.104 & 0.057 & 0.016 & 0.093 & 0.128 & 0.112 & 0.007 & 0.047 & 0.086 & 0.047 \\
\hline $\mathrm{Pb}$ & 0.027 & 0.159 & 0.218 & 0.027 & 0.155 & 0.139 & 0.037 & 0.167 & 0.117 & 0.103 \\
\hline $\mathrm{Sr}$ & 0.003 & 0.001 & & 0.004 & 0.007 & 0.001 & 0.001 & & 0.001 & 0.001 \\
\hline $\mathrm{Ca}$ & 0.011 & 0.027 & & 0.046 & 0.047 & 0.010 & 0.023 & & & \\
\hline Mn & 0.000 & 0.007 & 0.002 & 0.004 & 0.008 & 0.012 & 0.000 & 0.006 & 0.002 & \\
\hline $\mathrm{La}$ & 0.168 & 0.161 & 0.047 & 0.156 & 0.115 & 0.089 & 0.015 & 0.044 & 0.070 & 0.067 \\
\hline $\mathrm{Ce}$ & 0.299 & 0.492 & 0.631 & 0.294 & 0.404 & 0.365 & 1.018 & 0.435 & 0.560 & 0.704 \\
\hline $\operatorname{Pr}$ & 0.046 & 0.067 & 0.009 & 0.047 & 0.028 & 0.026 & 0.003 & 0.019 & 0.014 & 0.029 \\
\hline $\mathrm{Nd}$ & 0.077 & 0.093 & 0.009 & 0.077 & 0.044 & 0.032 & 0.011 & 0.036 & 0.035 & 0.069 \\
\hline $\mathrm{Sm}$ & 0.004 & 0.001 & & 0.005 & 0.004 & 0.003 & 0.001 & 0.001 & 0.002 & 0.002 \\
\hline $\mathrm{Eu}$ & 0.005 & 0.001 & 0.001 & 0.008 & 0.004 & 0.003 & 0.001 & 0.002 & 0.001 & 0.006 \\
\hline $\mathrm{Gd}$ & 0.000 & 0.006 & 0.008 & 0.002 & 0.007 & 0.007 & 0.019 & 0.007 & 0.006 & 0.011 \\
\hline Dy & 0.000 & 0.000 & & & & 0.000 & 0.000 & 0.003 & & \\
\hline $\mathrm{Er}$ & 0.002 & 0.001 & 0.002 & 0.000 & 0.000 & 0.001 & 0.002 & 0.003 & & \\
\hline $\mathrm{Y}$ & 0.020 & 0.005 & 0.001 & 0.016 & 0.005 & 0.011 & 0.002 & 0.023 & 0.059 & 0.010 \\
\hline Th & 0.004 & 0.006 & 0.006 & 0.002 & 0.019 & 0.015 & 0.308 & 0.060 & 0.015 & 0.048 \\
\hline$\Sigma \mathrm{A}$ & 0.779 & 1.089 & 0.953 & 0.819 & 1.029 & 0.920 & 1.459 & 0.873 & 1.205 & 1.275 \\
\hline $\mathrm{Fe}$ & 0.085 & 0.166 & 0.188 & 0.130 & 0.068 & 0.124 & 0.192 & 0.079 & 0.072 & 0.138 \\
\hline $\mathrm{Al}$ & 0.002 & 0.011 & 0.004 & 0.013 & 0.008 & 0.005 & 0.007 & 0.012 & 0.001 & 0.010 \\
\hline $\mathrm{Ti}$ & 0.440 & 0.235 & 0.140 & 0.454 & 0.256 & 0.306 & 0.201 & 0.436 & 0.420 & 0.302 \\
\hline $\mathrm{Si}$ & 0.005 & 0.013 & 0.007 & 0.007 & 0.201 & 0.289 & 0.031 & 0.227 & 0.115 & 0.075 \\
\hline $\mathrm{Nb}$ & 1.468 & 1.575 & 1.661 & 1.396 & 1.467 & 1.274 & 1.570 & 1.246 & 1.391 & 1.475 \\
\hline $\mathrm{Ta}$ & 0.000 & & 0.000 & & & 0.003 & & & & \\
\hline$\Sigma \mathrm{B}$ & 2.000 & 2.000 & 2.000 & 2.000 & 2.000 & 2.000 & 2.000 & 2.000 & 2.000 & 2.000 \\
\hline Vacancy & 1.221 & 0.911 & 1.047 & 1.181 & 0.971 & 1.080 & 0.541 & 1.127 & 0.795 & 0.725 \\
\hline
\end{tabular}

n.d $=$ not detected; calculated on the basis of 2 B-site cations. 
Table 7. Representative composition of iron and manganiferous laterites from Morro dos Seis Lagos deposit.

\begin{tabular}{|c|c|c|c|c|c|c|c|c|c|c|c|c|c|c|}
\hline \multirow[b]{2}{*}{$\%$} & \multirow{2}{*}{$\begin{array}{c}\text { Pisolitic } \\
\text { F1-02 }\end{array}$} & \multirow{2}{*}{$\begin{array}{c}\text { Fragmented } \\
\text { F1-03 }\end{array}$} & \multicolumn{2}{|c|}{ Mottled } & \multicolumn{2}{|c|}{ Upper Purple } & \multicolumn{2}{|c|}{ Manganiferous } & \multicolumn{2}{|c|}{ Lower Purple } & \multicolumn{4}{|c|}{ Brown } \\
\hline & & & F1-05 & F1-07 & F1-10 & F1-11 & F1-14 & F1-16 & F1-18 & F1-23 & F1-24 & F1-27 & F1-30 & F1-35 \\
\hline $\mathrm{SiO}_{2}$ & 0.64 & 0.78 & 0.36 & 0.12 & 0.2 & 0.21 & 0.49 & 0.47 & 2.1 & 0.68 & 0.75 & 1.04 & 0.53 & 1.85 \\
\hline $\mathrm{Al}_{2} \mathrm{O}_{3}$ & 1.78 & 1.82 & 2.37 & 1.56 & 0.86 & 0.43 & 0.23 & 0.55 & 0.8 & 0.54 & 0.4 & 0.5 & 0.38 & 0.77 \\
\hline $\mathrm{Fe}_{2} \mathrm{O}_{3}$ & 81.35 & 79.2 & 79.28 & 83.22 & 83.4 & 84.46 & 50.55 & 57.09 & 83.29 & 82.09 & 80.16 & 81.74 & 82.39 & 81.98 \\
\hline $\mathrm{MgO}$ & $<0.01$ & $<0.01$ & $<0.01$ & $<0.01$ & $<0.01$ & 0.02 & $<0.01$ & $<0.01$ & 0.44 & 0.04 & $<0.01$ & 0.01 & $<0.01$ & $<0.01$ \\
\hline $\mathrm{CaO}$ & $<0.01$ & 0.02 & $<0.01$ & $<0.01$ & $<0.01$ & 0.01 & $<0.01$ & $<0.01$ & 0.35 & 0.05 & $<0.01$ & $<0.01$ & $<0.01$ & 0.01 \\
\hline $\mathrm{Na}_{2} \mathrm{O}$ & $<0.01$ & 0.01 & $<0.01$ & $<0.01$ & $<0.01$ & 0.01 & $<0.01$ & 0.01 & 0.01 & $<0.01$ & $<0.01$ & $<0.01$ & $<0.01$ & $<0.01$ \\
\hline $\mathrm{K}_{2} \mathrm{O}$ & 0.02 & $<0.01$ & 0.02 & $<0.01$ & $<0.01$ & 0.02 & 0.02 & 0.04 & 0.04 & 0.02 & 0.02 & $<0.01$ & $<0.01$ & $<0.01$ \\
\hline $\mathrm{TiO}_{2}$ & 3.46 & 3.25 & 2.33 & 2.88 & 6.14 & 7.23 & 0.06 & 1.31 & 1.07 & 2.23 & 2.06 & 0.99 & 0.57 & 0.37 \\
\hline $\mathrm{P}_{2} \mathrm{O}_{5}$ & 0.87 & 1.74 & 1.53 & 1.14 & 0.47 & 0.16 & 0.21 & 0.33 & 0.16 & 0.38 & 0.46 & 0.4 & 0.29 & 0.58 \\
\hline $\mathrm{MnO}$ & 0.07 & 0.07 & 0.02 & 0.26 & 0.24 & 0.21 & 32.2 & 25.27 & 0.22 & 0.36 & 0.23 & 0.39 & 0.31 & 0.43 \\
\hline LOI & 9.3 & 10.5 & 12.1 & 8.4 & 6.0 & 4.0 & 9.2 & 9.1 & 8.1 & 9.7 & 10.3 & 10.9 & 10.6 & 11.8 \\
\hline \multicolumn{15}{|l|}{ ppm } \\
\hline $\mathrm{Nb}$ & 10419.3 & 10744.5 & 8194.3 & 7772.3 & 9969.8 & 13217.1 & 796.6 & 5075.2 & 8253.3 & 13311.2 & 21548.1 & 10983.6 & 5444.1 & 3419.1 \\
\hline $\mathrm{Ta}$ & 0.5 & 0.7 & 0.5 & 0.2 & 0.1 & 0.3 & 0.1 & 0.4 & $<0.1$ & $<0.1$ & 0.2 & $<0.1$ & $<0.1$ & $<0.1$ \\
\hline $\mathrm{La}$ & 474.4 & 730.0 & 667.4 & 807.1 & 415.7 & 319.2 & 262.6 & 480.0 & 343.4 & 980.8 & 1622.0 & 1042.9 & 503.2 & 1560.5 \\
\hline $\mathrm{Ce}$ & 1695.1 & 2304.7 & 1536.4 & 2637.6 & 1857.8 & 2365.0 & 11156.7 & 4233.4 & 10041.6 & 5224.4 & 5185.6 & 9331.7 & 28520.6 & 4500.2 \\
\hline $\operatorname{Pr}$ & 78.65 & 134.89 & 118.07 & 123.85 & 68.26 & 75.9 & 89.57 & 113.05 & 101.81 & 281.66 & 591.76 & 252.42 & 105.77 & 248.77 \\
\hline $\mathrm{Nd}$ & 202.7 & 373.3 & 323.3 & 298.3 & 166.9 & 117.7 & 302.5 & 341.4 & 187.9 & 492.9 & 1413.4 & 407.3 & 226.4 & 627.1 \\
\hline $\mathrm{Sm}$ & 32.86 & 52.05 & 41.23 & 47.89 & 32.04 & 22.58 & 73.24 & 70.96 & 38.01 & 57.91 & 152.59 & 53.03 & 41.47 & 74.66 \\
\hline $\mathrm{Eu}$ & 9.7 & 13.05 & 9.33 & 14.87 & 11.96 & 7.72 & 22.09 & 22.96 & 14.67 & 19.89 & 40.94 & 13.6 & 12.13 & 17.00 \\
\hline $\mathrm{Gd}$ & 39.45 & 30.39 & 30.76 & 60.24 & 61.58 & 38.15 & 154.91 & 62.03 & 52.97 & 76.18 & 116.34 & 35.61 & 63.22 & 36.81 \\
\hline $\mathrm{Tb}$ & 4.23 & 4.18 & 2.55 & 5.82 & 8.34 & 3.75 & 11.21 & 9.77 & 9.53 & 12.63 & 19.95 & 6.02 & 5.38 & 5.18 \\
\hline Dy & 17.09 & 16.16 & 8.98 & 20.87 & 39.68 & 14.77 & 40.04 & 43.86 & 51.14 & 65.38 & 101.29 & 32.43 & 28.26 & 25.65 \\
\hline Ho & 2.85 & 2.59 & 1.3 & 3.62 & 7.11 & 2.46 & 6.13 & 6.98 & 8.98 & 11.07 & 18.01 & 6.63 & 4.25 & 3.77 \\
\hline Er & 5.95 & 5.96 & 3.24 & 7.68 & 14.96 & 5.94 & 13.1 & 16.42 & 22.78 & 25.32 & 39.99 & 17.86 & 10.00 & 8.83 \\
\hline $\mathrm{Tm}$ & 0.75 & 0.73 & 0.36 & 0.92 & 1.83 & 0.89 & 1.67 & 2.00 & 2.72 & 2.99 & 4.7 & 2.32 & 1.48 & 1.21 \\
\hline $\mathrm{Yb}$ & 4.26 & 4.37 & 2.14 & 5.5 & 8.67 & 4.56 & 8.75 & 10.37 & 14.95 & 16.35 & 24.83 & 13.37 & 8.28 & 6.39 \\
\hline $\mathrm{Lu}$ & 0.59 & 0.51 & 0.25 & 0.62 & 1.29 & 0.67 & 1.14 & 1.39 & 1.97 & 2.06 & 3.15 & 1.61 & 0.92 & 0.78 \\
\hline Y & 71.2 & 74.3 & 28.5 & 105.2 & 220.1 & 64.1 & 163.5 & 203.5 & 256.8 & 377.0 & 558.4 & 168.5 & 88.1 & 97.1 \\
\hline Sc & 241 & 194 & 146 & 261 & 368 & 350 & 243 & 193 & 433 & 381 & 382 & 482 & 285 & 417 \\
\hline $\mathrm{Rb}$ & 0.9 & 0.5 & 1.1 & $<0.1$ & $<0.1$ & 1.6 & 0.2 & 0.6 & 0.9 & 0.4 & 0.6 & 0.1 & 0.2 & $<0.1$ \\
\hline $\mathrm{Ba}$ & 367 & 448 & 315 & 868 & 783 & 738 & 44024 & 34729 & 518 & 753 & 1810 & 557 & 431 & 978 \\
\hline $\mathrm{Sr}$ & 66.2 & 101.4 & 83.1 & 237.9 & 90.5 & 41.1 & 19.1 & 49.9 & 25.1 & 81.4 & 161.5 & 75.9 & 107.2 & 236.0 \\
\hline $\mathrm{Pb}$ & 200.9 & 139.6 & 113.8 & 231.8 & 306.6 & 278.7 & 261.4 & 211.5 & 172.1 & 172.3 & 174.0 & 509.6 & 395.0 & 199.6 \\
\hline Th & 2989.7 & 2224.5 & 1943.0 & 2856.8 & 2723.9 & 1956.2 & 2076.5 & 1216.5 & 1826.7 & 3234.9 & 2186.0 & 3451.5 & 2314.0 & 2373.6 \\
\hline $\mathrm{U}$ & 0.5 & 0.8 & 0.8 & 0.3 & 0.1 & 0.2 & $<0.1$ & 0.2 & 0.1 & 0.2 & 0.4 & 0.8 & 0.5 & 0.2 \\
\hline $\mathrm{Zr}$ & 188.1 & 204.5 & 147.1 & 75.3 & 54.7 & 49.7 & 32.0 & 70.6 & 38.4 & 88.3 & 108.8 & 109.4 & 39.8 & 18.2 \\
\hline $\mathrm{Hf}$ & 5.5 & 5.4 & 3.7 & 2.0 & 1.4 & 3.2 & 0.7 & 1.9 & 1.0 & 3.2 & 3.5 & 3.8 & 1.3 & 0.7 \\
\hline Co & 7.8 & 8.2 & 2.9 & 21.4 & 27.7 & 14.9 & 222.4 & 144.2 & 35.8 & 87.0 & 33.0 & 41.1 & 51.1 & 43.8 \\
\hline $\mathrm{V}$ & 183 & 201 & 291 & 118 & 162 & 191 & 20 & 106 & 116 & 262 & 377 & 208 & 125 & 122 \\
\hline W & 203.5 & 208.8 & 168.4 & 172.4 & 326.5 & 380.2 & 11.1 & 84.1 & 128.2 & 195.6 & 193.5 & 88.1 & 38.3 & 30.8 \\
\hline $\mathrm{Zn}$ & 328 & 287 & 118 & 896 & 1560 & 2287 & 1444 & 1296 & 2201 & 2079 & 2391 & 1543 & 1592 & 1553 \\
\hline $\mathrm{Cu}$ & 5.7 & 7.2 & 4.6 & 7.3 & 4.3 & 2.6 & 6.2 & 8.1 & 11.5 & 4.1 & 5.0 & 7.0 & 22.9 & 7.6 \\
\hline $\mathrm{F}$ & 210 & 171 & 90 & 210 & 130 & 160 & 210 & 142 & 201 & 99 & 209 & 583 & 310 & 503 \\
\hline
\end{tabular}

Table 8. Concentrations of $\mathrm{Nb}_{2} \mathrm{O}_{5}, \mathrm{TiO}_{2}$ and REE of the Morro dos Seis Lagos deposit.

\begin{tabular}{|c|c|c|c|c|c|c|c|c|c|c|c|c|c|c|c|}
\hline \multirow{2}{*}{ Laterites } & \multicolumn{3}{|c|}{$\mathrm{Nb}_{2} \mathrm{O}_{5}$} & \multicolumn{3}{|c|}{$\mathrm{TiO}_{2}$} & \multicolumn{3}{|c|}{$\mathrm{CeO}_{2}$} & \multicolumn{3}{|c|}{$\mathrm{LREE}_{2} \mathrm{O}_{3}-\mathrm{CeO}_{2}$} & \multicolumn{3}{|c|}{$\mathrm{HREE}_{2} \mathrm{O}_{3}$} \\
\hline & Min. & Max. & Avg. & Min. & Max. & Avg. & Min. & Max. & Avg. & Min. & Max. & Avg. & Min. & Max. & Avg. \\
\hline Pisolitic & 2.98 & 6.14 & 4.56 & 3.46 & 7.57 & 5.52 & 0.12 & 0.17 & 0.15 & 0.18 & 0.19 & 0.18 & 0.01 & 0.02 & 0.01 \\
\hline Fragmented & 2.24 & 3.07 & 2.54 & 3.10 & 3.39 & 3.25 & 0.13 & 0.29 & 0.24 & 0.19 & 0.33 & 0.28 & 0.01 & 0.02 & 0.01 \\
\hline Mottled & 2.22 & 10.55 & 5.04 & 2.33 & 14.68 & 6.63 & 0.19 & 0.77 & 0.43 & 0.27 & 1.31 & 0.63 & 0.01 & 0.03 & 0.02 \\
\hline Upper Purple & 0.72 & 3.25 & 2.38 & 0.44 & 7.23 & 4.99 & 0.19 & 0.56 & 0.32 & 0.06 & 0.20 & 0.14 & 0.01 & 0.03 & 0.02 \\
\hline Manganiferous & 0.23 & 1.45 & 0.62 & 0.06 & 1.31 & 0.45 & 0.52 & 1.37 & 0.90 & 0.06 & 0.24 & 0.13 & 0.04 & 0.05 & 0.05 \\
\hline Lower Purple & 2.13 & 5.73 & 3.62 & 1.07 & 4.01 & 2.29 & 0.38 & 1.23 & 0.75 & 0.16 & 1.05 & 0.46 & 0.04 & 0.09 & 0.05 \\
\hline
\end{tabular}



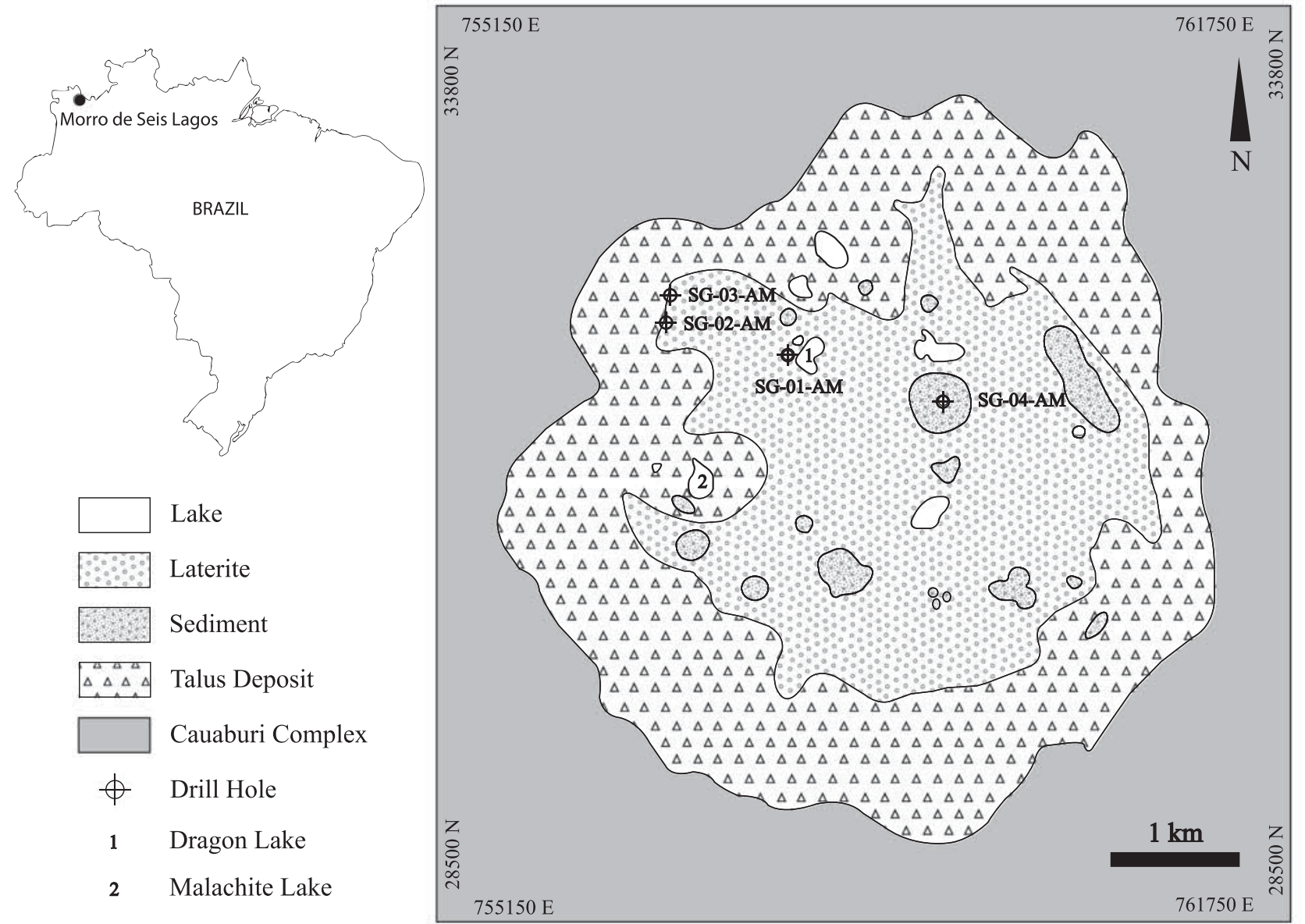


\section{ACCEPTED MANUSCRIPT}

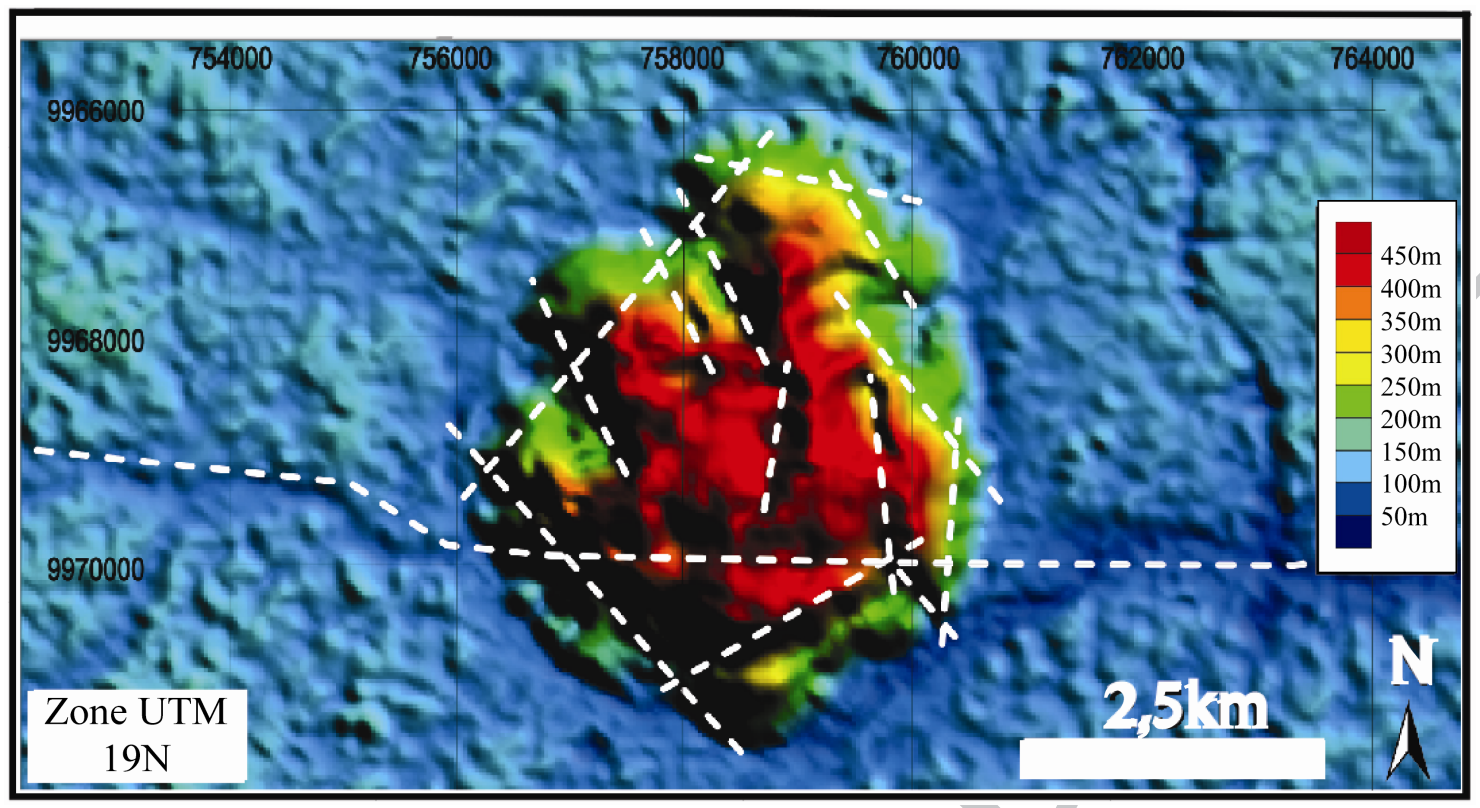




\section{ACCEPTED MANUSCRIPT}
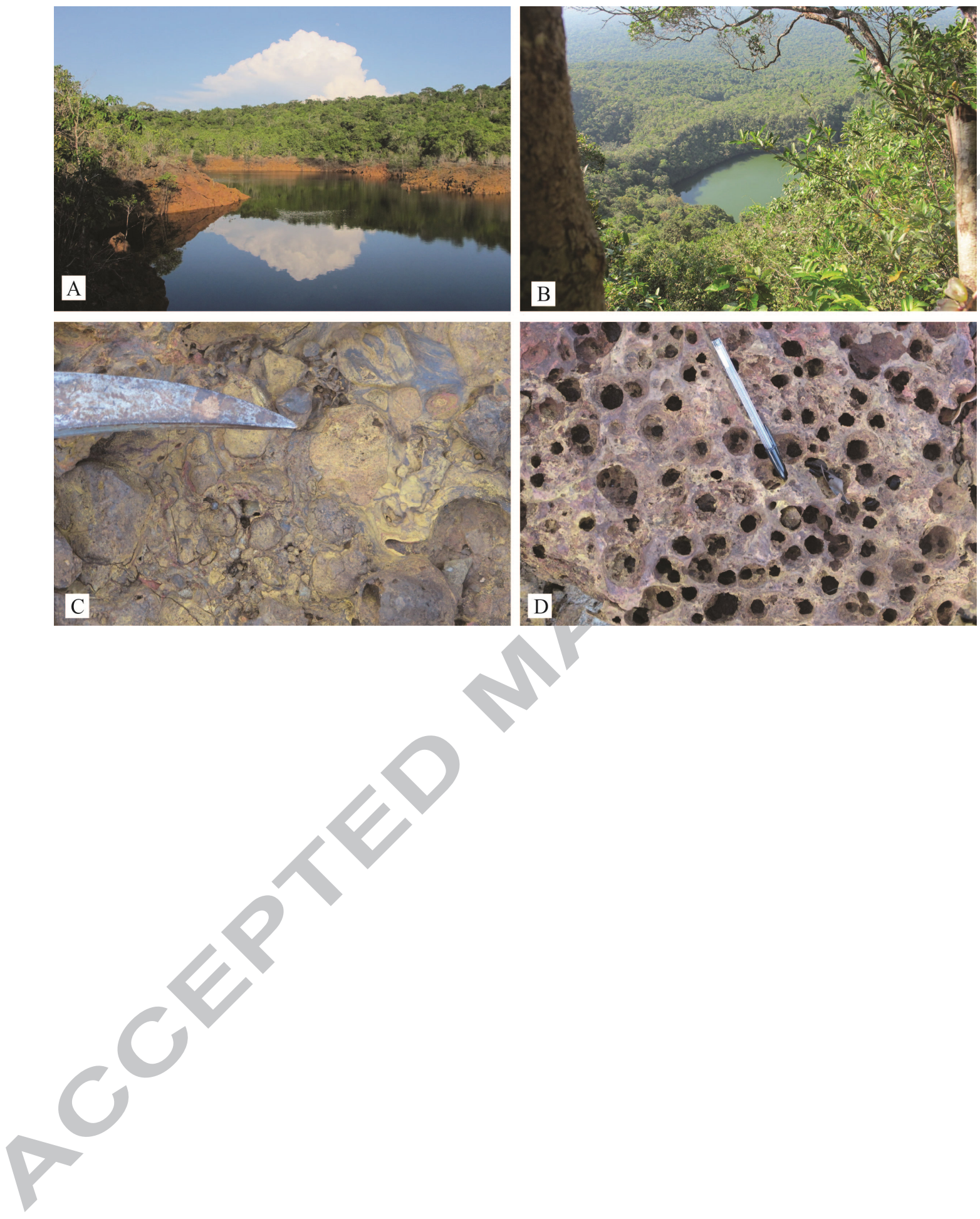


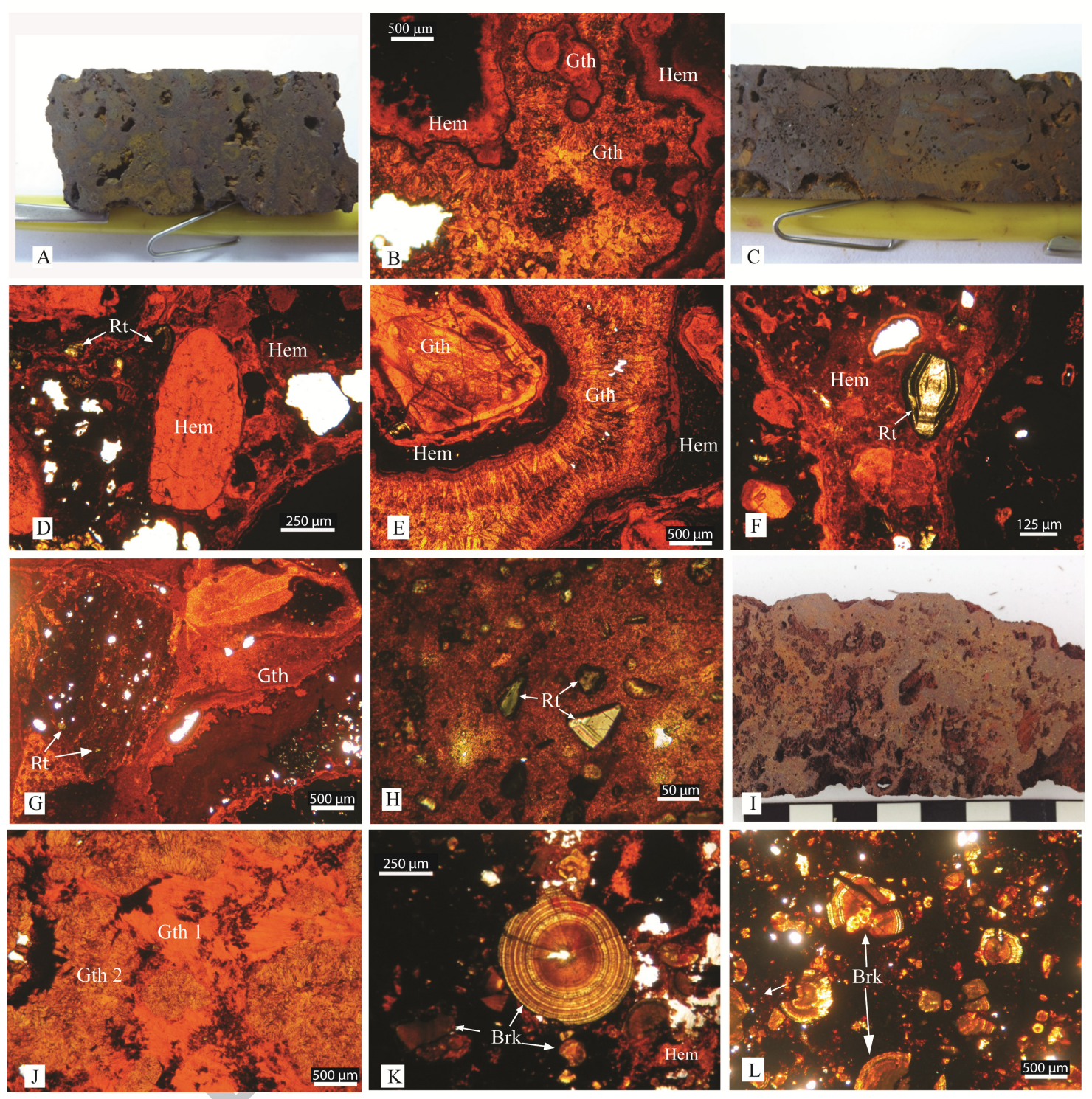



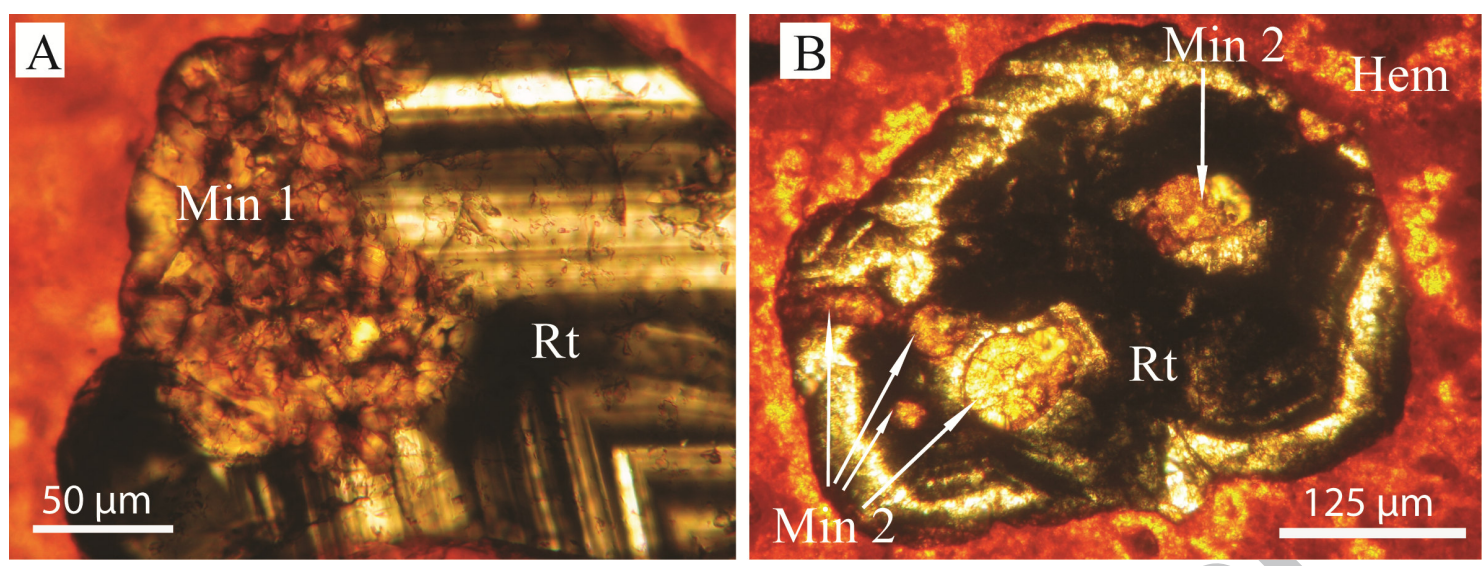

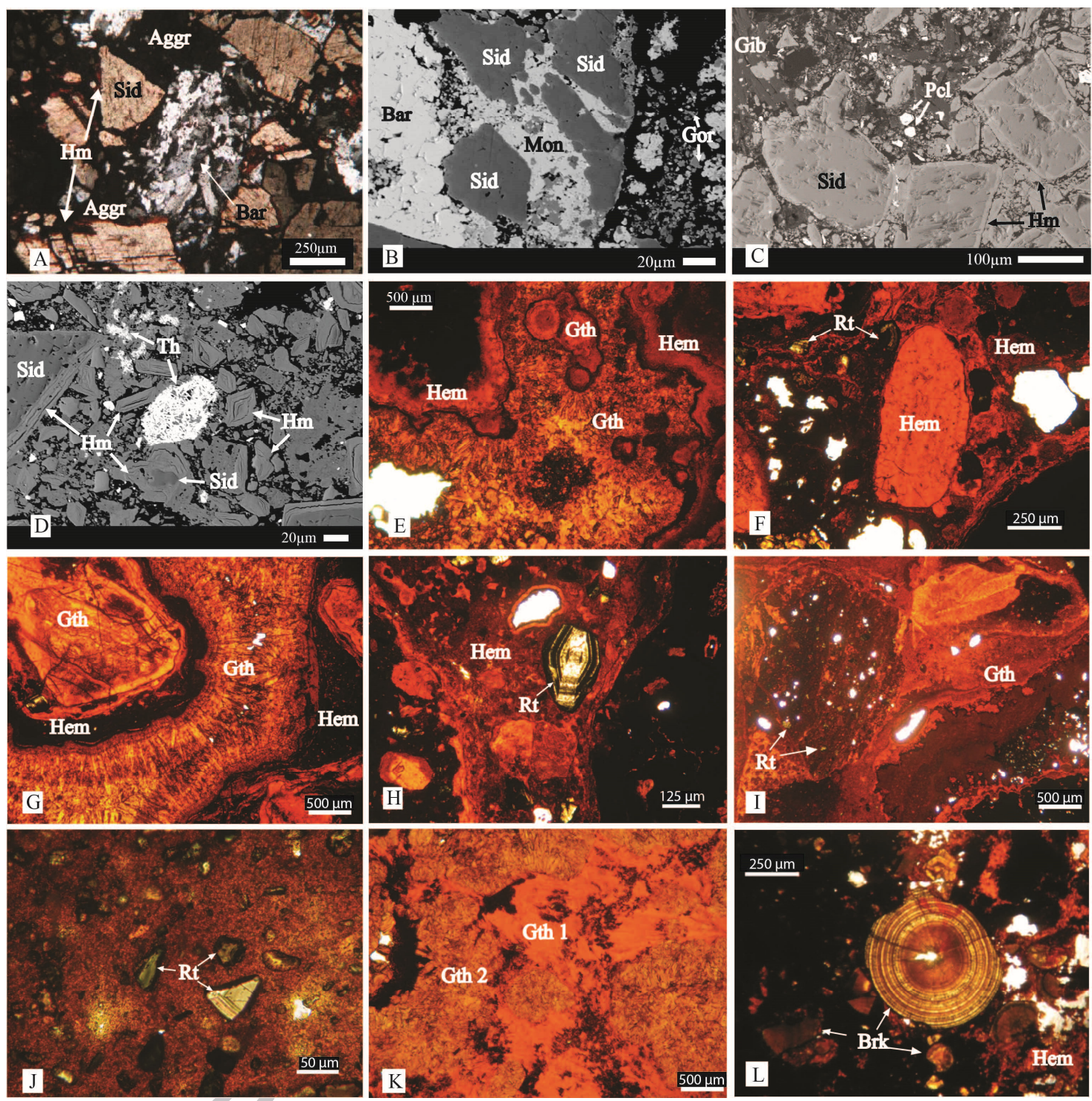

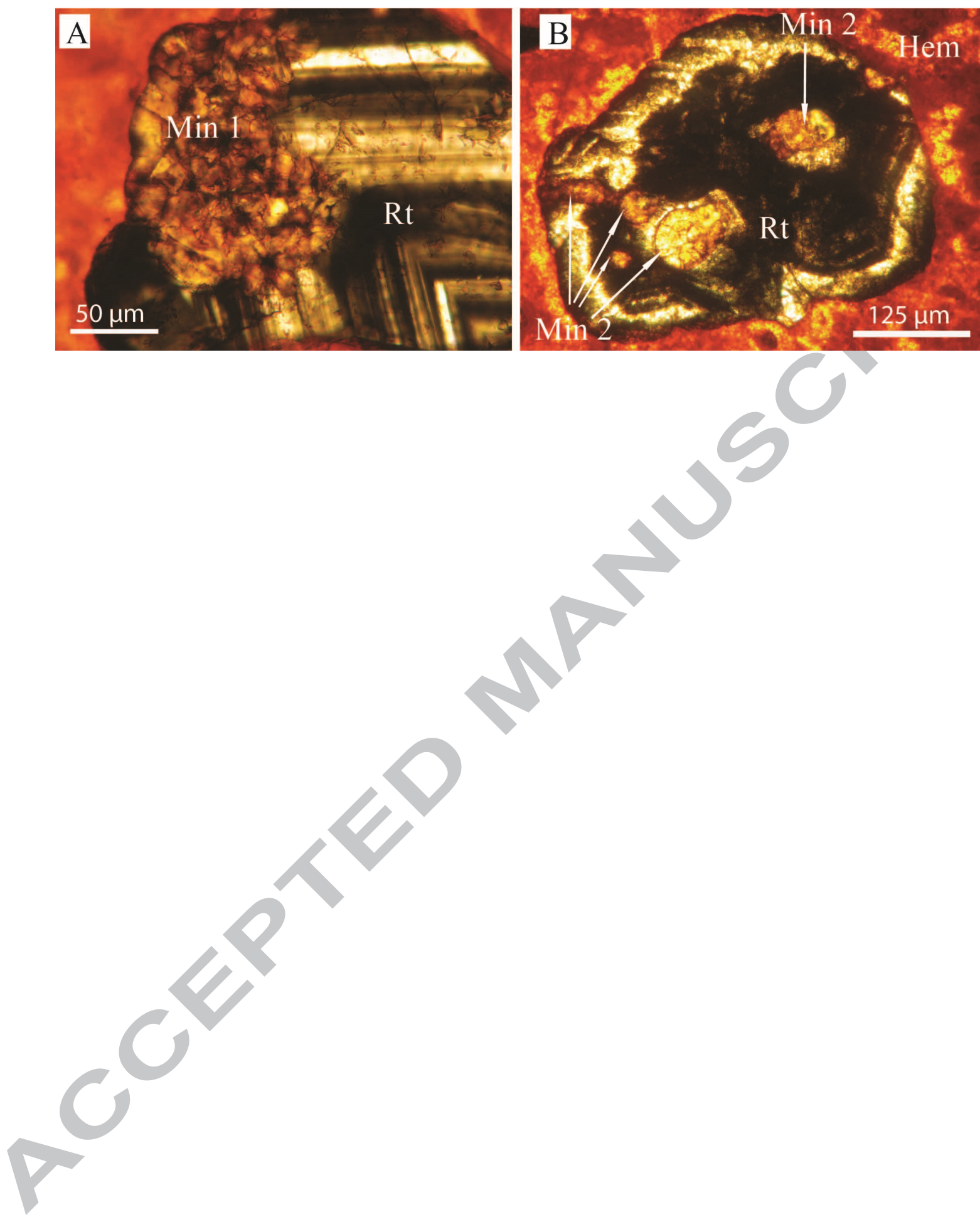

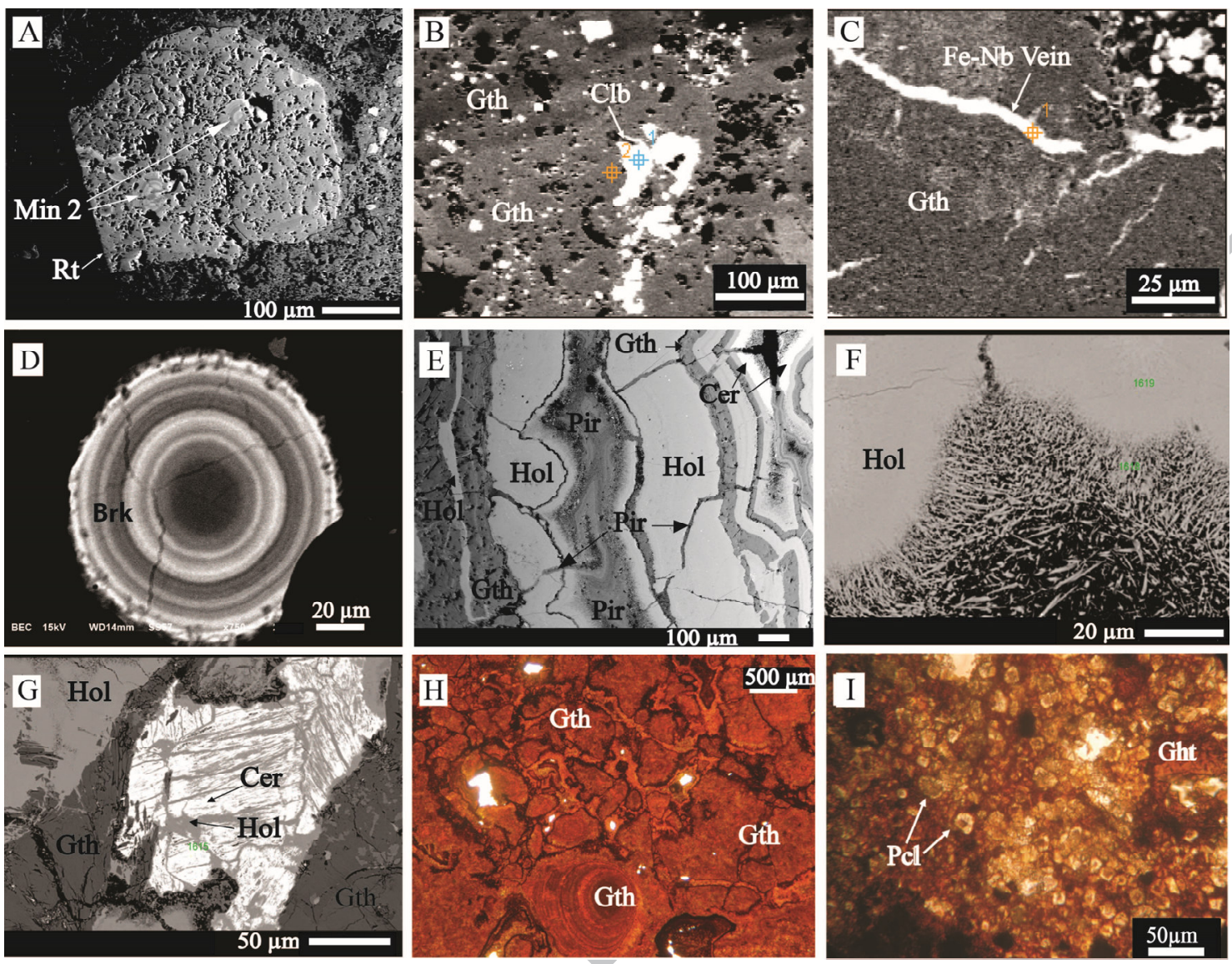

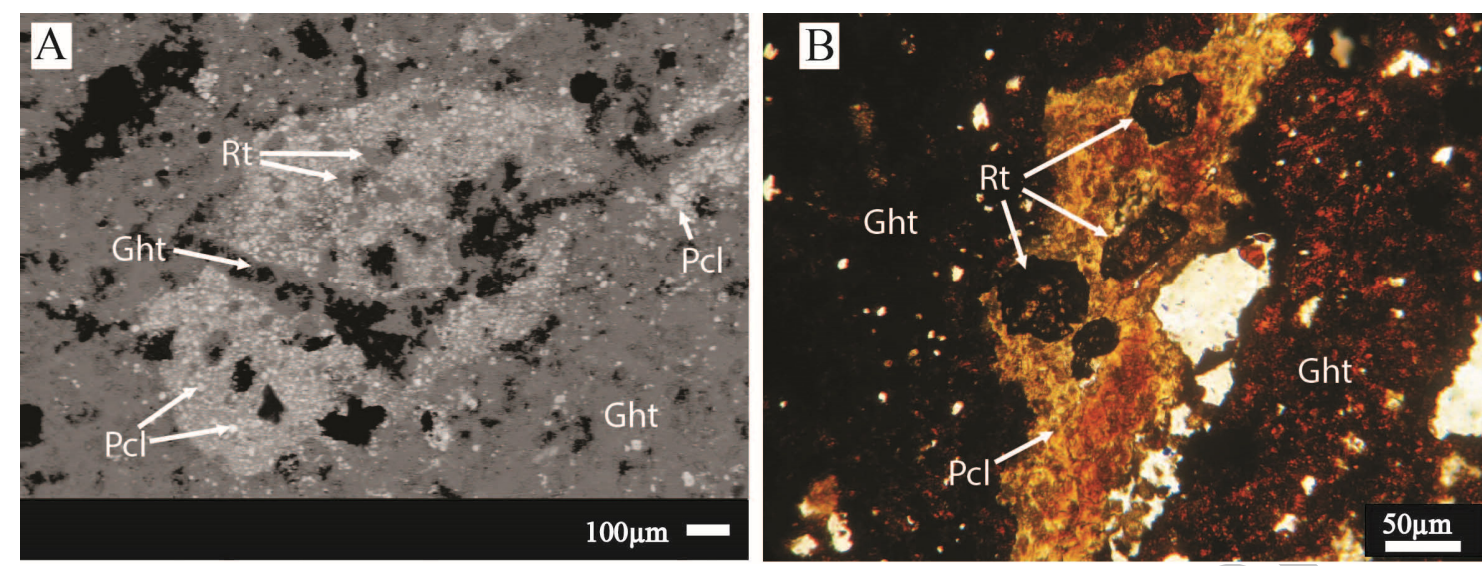
The Morro dos Seis Lagos deposit is the world largest Nb-deposit

Laterite mineralization is associated to siderite carbonatite

Six textural and compositional types of laterite

Pyrochlore breakdown formed $\mathrm{Nb}$-rich rutile and $\mathrm{Nb}$-bearing goethite

$\mathrm{Nb}$-rich rutile altered to brookite 